\title{
5-Aminolevulinic acid (ALA) biosynthetic and metabolic pathways and its role in higher plants: a review
}

\author{
Yue $\mathrm{Wu}^{1} \cdot$ Weibiao Liao ${ }^{1} \cdot$ Mohammed Mujitaba Dawuda ${ }^{1,2} \cdot$ Linli Hu$^{1} \cdot$ Jihua Yu $^{1}$ (1)
}

Received: 17 February 2018 / Accepted: 26 November 2018 / Published online: 17 December 2018

(c) The Author(s) 2018

\begin{abstract}
Crop productivity is restricted by various abiotic stresses such as drought, salinity, heat, and cold. Many efforts have been taken to decrease the inhibition of plant growth by alleviating the abiotic stresses. Exogenous applications of hormones, plant growth regulators, and/or small signaling molecules have been reported as a means to enhance plant resistance to stress. One of the small signaling molecules utilized is 5-aminolevulinic acid (ALA) that has been shown to enhance plant growth under abiotic stress. As a metabolic intermediate in higher plants, ALA is a precursor of all tetrapyrroles such as chlorophyll, heme and siroheme. The pathway towards biosynthesis upstream and the metabolism downstream of ALA contains multiple regulatory points that are affected by positive/negative factors. However, report about the regulatory aspects of the ALA metabolic pathway and the role of ALA in stimulating physiochemical processes in higher plants under stress have not been collated and summarized systematically. In this regard, we summarize recent developments in understanding the mechanisms of plant responses to abiotic stress which are affected by ALA as well as new information on the metabolic pathway of ALA. We find that exogenous application of ALA can enhance some key physiological and biochemical processes in plants such as photosynthesis, nutrient uptake, antioxidant characteristics and osmotic equilibrium, however, more in-depth research on the specific mechanisms are needed.
\end{abstract}

Keywords 5-Aminolevulinic acid (ALA) $\cdot$ Biosynthetic pathway $\cdot$ Metabolic pathway $\cdot$ Abiotic stress $\cdot$ Plant growth regulator $\cdot$ Stress tolerance

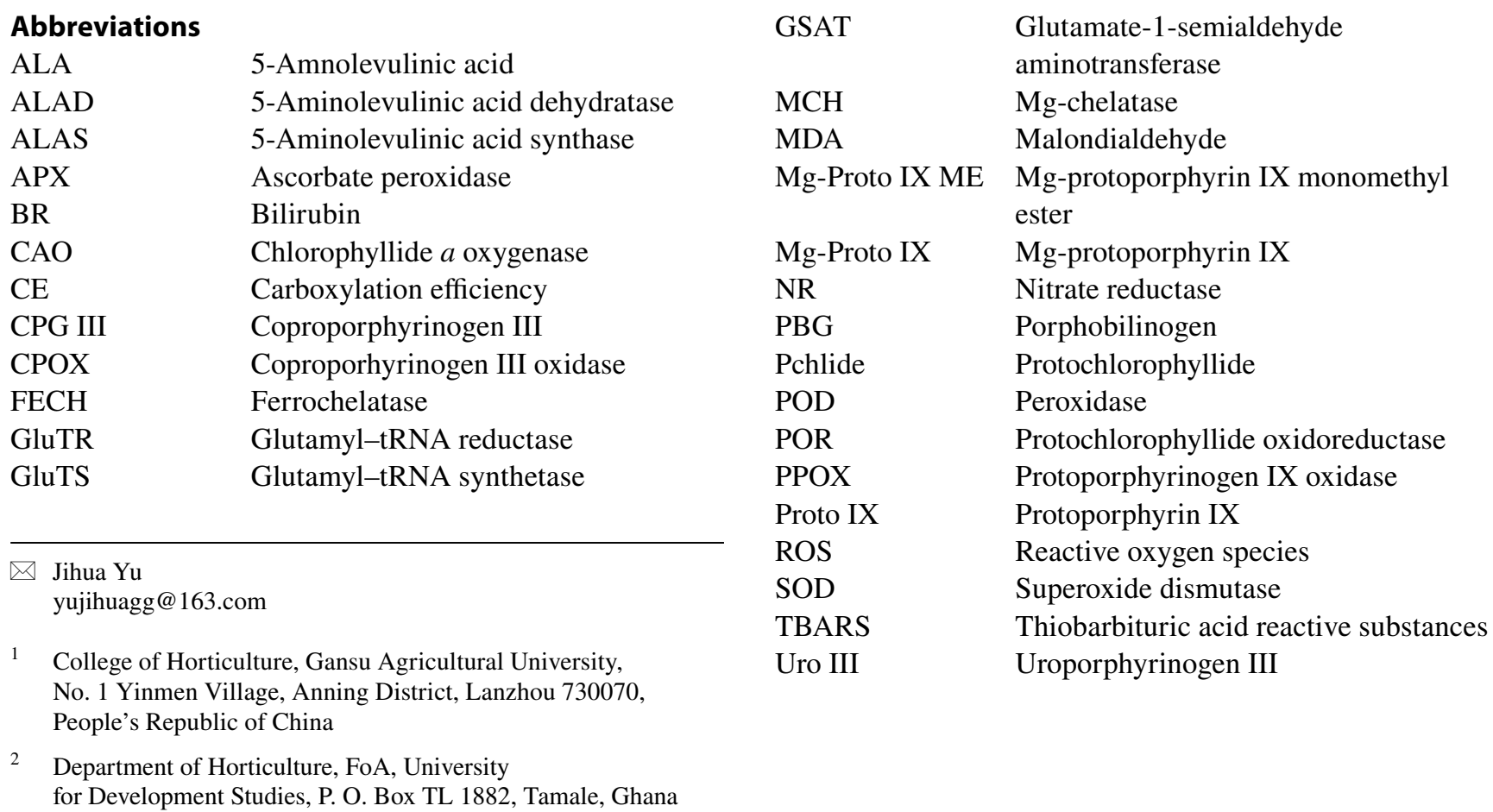




\section{Introduction}

Variable climatic conditions, limited arable land and decreased water availability are threatening agricultural sustainability in many regions on the planet (Mickelbart et al. 2015). These challenges, coupled with various abiotic stresses, such as drought, salinity, heat, and cold, causes significant crop yield losses and its associated socioeconomic consequences. For example, severe drought resulted in the decline of maize (Zea mays L.) yield in the United States (Boyer et al. 2013); the rapid decline of groundwater at Fertile Crescent caused widespread crop failure which compelled some of the affected farm families to migrate (Kelley et al. 2015); severe heat stress (above $40^{\circ} \mathrm{C}$ ) led to the failure of a large area of sorghum (Sorghum bicolor L.) in northeast Australia (Lobell et al. 2015). Also, some of the human activities, such as intensive irrigation, poor drainage, and uncontrolled mining led to waterlogging and accelerated the salinization of cultivated lands worldwide (Herbert et al. 2015; Singh 2015). Therefore, the improvement of crop tolerance to abiotic stresses is becoming a prioritized area of research in agricultural science.

Exogenous application of various small molecules or plant growth regulators is a well-known method to enhance the resistance of plants to environmental stresses (Chan and Shi 2015). Among the many identified hormones, regulators or small signaling molecules, 5-aminolevulinic acid (ALA) is known to be effective against the harmful effects caused by various abiotic stresses in plants. It has been reported in several studies that ALA was involved in the regulation of plant growth and development, and has physiological activity as plant hormone; therefore, it can be used as a plant growth regulator in agricultural production (Bindu and Vivekanandan 1998; Akram and Ashraf 2013).

As the common precursor of all tetrapyrroles in biological world, ALA has been reported as a light-sensitive reagent by medical field in fluorescence diagnosis and photodynamic therapy (Guaragna et al. 2015; Hillemanns et al. 2017). ALA and its derivatives have been used in the treatments of actinic keratosis and basal-cell carcinoma of skin, since they release free radicals and singlet oxygen during the transversion from excited state to the ground state when motivated by light, which provide cellular toxicity to target cancer cells (Cosgarea et al. 2013; Morton et al. 2013).

Originally, ALA was discovered in duck blood in 1953, and was identified as the source of protoporphyrin (Shemin and Russell 1953). A few decades later, ALA was found in the culture-medium of Chlorella vulgaris when added with levulinic acid, a competitive inhibitor to
ALA dehydratase that hold back the decurrent metabolization of ALA (Beale 1970). ALA has regulating effects towards certain metabolic processes, such as chlorophyll, heme and siroheme biosynthesis (Kim et al. 2014). As a precursor of chlorophyll in higher plants, the early evidence of ALA metabolism was found in corn (Z. mays L.), seedlings of common bean (Phaseolus vulgaris L.) and cotyledons of cucumber (Cucumis sativus L.) (Harel and Klein 1972; Beale and Castelfranco 1974). The biosynthetic pathway of ALA in green plant tissues, namely $\mathrm{C}_{5}$-pathway, requires L-glutamate (Glu) to provide carbon skeleton (Hudson et al. 2011). Glutamate-tRNA reductase enzyme (GluTR), which is encoded by HEMAl, is the key rate-limiting enzyme in this pathway (Apitz et al. 2016).

ALA was considered a critical regulator to plants. Studies towards understanding the regulatory mechanism of ALA in plants have become a key area of research in agricultural science (Czarnecki et al. 2011; Xie et al. 2013; Ali et al. 2014b). Studies have shown the mitigation role of ALA in plants against abiotic stresses when used as an exogenous supplement, but the regulation mechanisms associated with the stress tolerance have not been fully elucidated.

A few excellent reviews have elaborated the physiochemical aspects and regulatory functions of ALA in plants. For example, in a review, the authors have discussed the potential of microbial production of ALA and their application in agricultural crops and medical treatments (Sasaki et al. 2002). In another review article, the authors have highlighted the primary roles of ALA with different modes of action in alleviating abiotic stresses (Akram and Ashraf 2013). However, there is a lack of detailed information with regard to the regulative manner on biosynthesis upstream and metabolism downstream of ALA in plants. Little has been reported in the scientific literature regarding the role of ALA in promoting/regulating plant growth and alleviating damages caused by abiotic stresses through the visual angle from ALA metabolic pathway. The present review starts to fill this knowledge gap.

\section{The biosynthesis of ALA in higher plants}

All tetrapyrroles in vivo, including chlorophyll, heme, siroheme, vitamin $\mathrm{B}_{12}$ and phytochromobilin are derived from a common precursor, that is, ALA (Senge et al. 2014). The biosynthesis of ALA is a momentous bioprocess in both heterotroph organisms and photosynthetic species. In heterotroph organisms, the biosynthetic pathway of ALA is called Shemin pathway or $\mathrm{C}_{4}$-pathway (Bradshaw et al. 1993; Neidle and Kaplan 1993), whereas in photosynthetic species, such as plants, algae and most photosynthetic bacteria and archaea, it is called Beale pathway, or also known as the $\mathrm{C}_{5}$-pathway 
Fig. 1 The biosynthetic pathway of ALA in higher plants. The main biosynthetic pathway of ALA in higher plants was called Beal pathway or $\mathrm{C}_{5}$-pathway. This pathway starts from glutamic acid, which is produced by TCA cycle. Glu ligates tRNA $^{\text {Glu }}$ and generates GlutRNA are catalyzed by GluTS. Then, GluTR acts a catalyzing role that converts Glu-tRNA into GSA. At last, catalyzed by GSAT, ALA is created in stroma of chloroplast

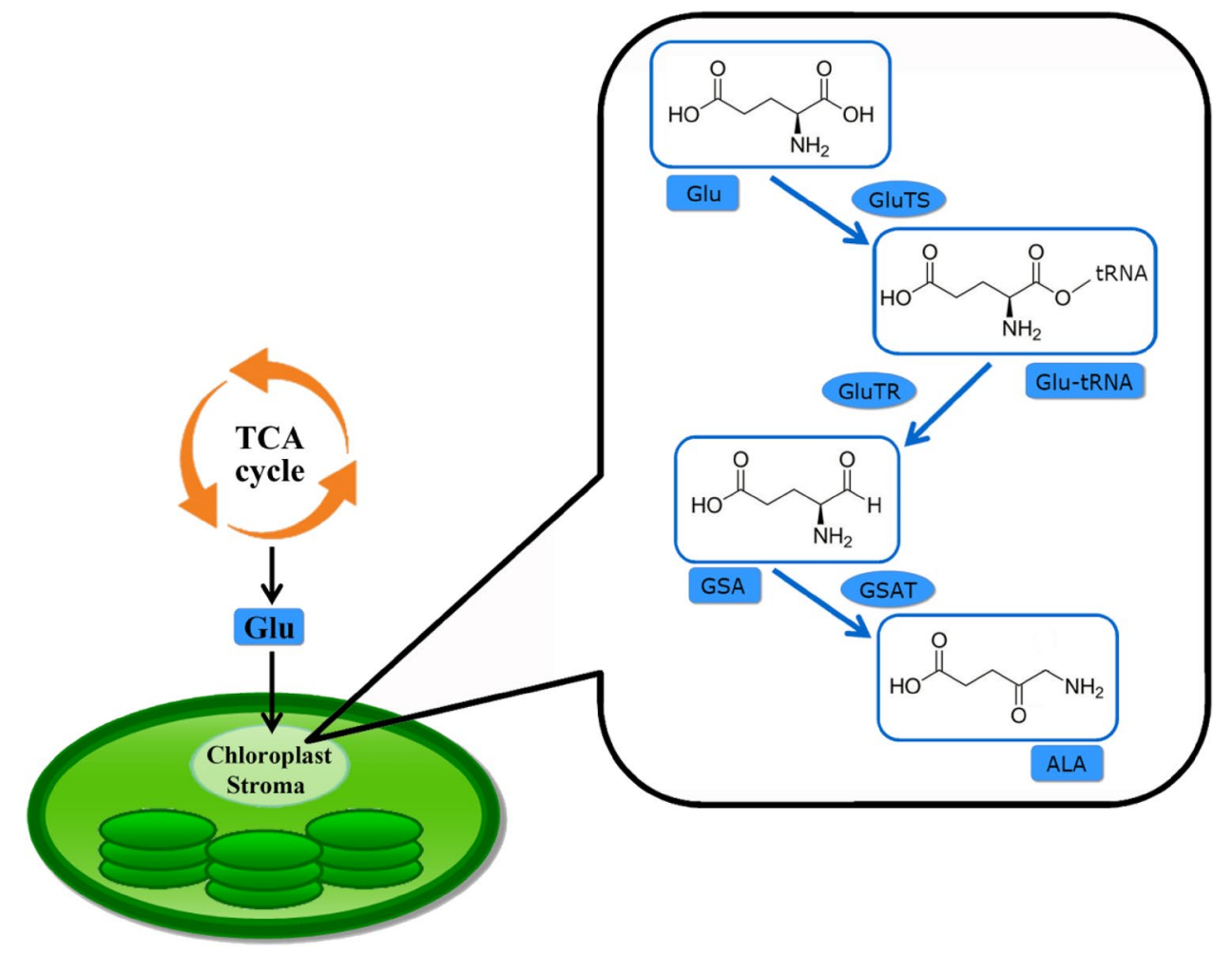

or the monovinyl/divinyl monocarboxylic acid cycle. The $\mathrm{C}_{5}$-pathway serves as the dominant process in photosynthetic species (Fig. 1) (Kořený et al. 2013; Akram and Ashraf 2013). L-Glutamate is the source of ALA synthesis in the Beale Pathway, it ligates tRNA ${ }^{\text {Glu }}$ and generates L-glutamy-tRNA ultimately; this reaction is simultaneously catalyzed by glutamyl-tRNA synthetase (GluTS) (Czarnecki and Grimm 2012). Then, GluTR plays a catalyzing role where the carboxyl group of Glu-tRNA is reduced to formyl group; this process enables the conversion of L-Glu-tRNA into L-glutamic acid 1-semialdehyde (GSA) (Tanaka and Tanaka 2007). At the last step, ALA is created through transamination, which catalyzed by glutamate-1-semialdehyde aminotransferase (GSAT) (Akram and Ashraf 2013). These reactions are located in stroma of chloroplast (Wang and Grimm 2015). GluTR plays a key role during the synthesis pathway of ALA, to some extent; it adjusts content of ALA and has rate-limiting effect to ALA biosynthesis (Zhao et al. 2014). In higher plants, this reductase is encoded by HEMAl (Nagahatenna et al. 2015). A study has shown that the regulating response of GluTR gene may be controlled by various stimulus, like plant hormone, light and circadian rhythms (Apitz et al. 2016). In the transgenic Arabidopsis thaliana expressed antisense HEMA1 mRNA, the protein content of GluTR decreased significantly, with the lowest protein content being only $1 \%$ of the non-transgenic plants (Kumar and
Söll 2000). The protein content of GSAT in the transgenic A. thaliana was not significantly different compared with the control, whereas ALA content was $21-56 \%$ of the control plants. These results indicate that expression level of HEMA1 inevitably influence the catalytic action of GluTR on Beale pathway. Sustained high light $(1500-1600 \mu \mathrm{E} /$ $\mathrm{m}^{2} / \mathrm{s}$ ) gravely restrained protein content of GluTR in cucumber cotyledons and ALA biosynthesis was declined with no suppression to HEMAl gene expression, but the protein content of GSAT remained unchanged (Aarti et al. 2007). This indicates that high light has a negative impact toward GluTR mainly on the transciriptional level. Moreover, during de-etiolation, the HEMAl and Lhcb are executed like co-ordinated regulation under parallel light by shared phytochrome- and cryptochrome-signalling pathways (McCormac and Terry 2002). In addition, GluTR can be impacted according to content of metabolic products on the downstream of ALA. Heme is an end-product in one of metabolic fluxes of ALA, and it is described as a feedback inhibitor to ALA formation, since it depresses the activity of GluTR (Zhang et al. 2015c). Similar phenomenon of feedback regulation also emerged in another metabolic branch of ALA, the Mg-branch. In a study with barley (Hordeum vulgare L.), the protochlorophyllide (Pchlide) performed a rapid accumulation after transition from light to dark and ALA formation whittled down immediately in the leaves (Richter et al. 2010). 


\section{The metabolism and regulation at downstream pathway of ALA}

\section{The common steps}

Tetrapyrroles, like chlorophyll, heme, siroheme, vitamin $\mathrm{B}_{12}$, and phytochromobilin, are ring structured intermediates; they participate in many biochemical processes and have vital roles in vivo. Within the downstream metabolic flux of ALA, they own a stretch of common steps, from ALA to uroporphyrinogen III (Uro III). After ALA biosynthesis, two ALA molecules are coalesced to form a pyrrol ring, called porphobilinogen (PBG); this reaction is catalyzed by ALA dehydratase (ALAD), and can be inhibited by aluminum and mercury (Pereira et al. 2006; Gupta et al. 2013). Then, four molecules of PBG catalyzed by PBG deaminase are polymerized to produce a linear tetrapyrrole, 1-hydroxymethylbillane (HMB); this is the essential linear tetrapyrrole ring of all tetrapyrroles. Therefore, under the catalytic condition of uroporphyrinogen III synthase (UROS), HMB forms the unsymmetrical closed macrocycle, Uro III (Fig. 2) (Tanaka and Tanaka 2007).

\section{Siroheme}

The starting point to the first branch of ALA metabolic flux is siroheme biosynthesis (Fig. 2). Transmethylation occurs to Uro III by a $S$-adenosyl-methionine: uroporphyrinogen III methyltransferase (SUMT), which forms dihydrosirohydrochlorin (also known as precorrin-2) (Storbeck et al. 2011). It gives sirohydrochlorin when precorrin-2 is subsequently catalyzed by an oxidase (precorrin-2 oxidase, PCOX); finally, sirohydrochlorin ferrochelatase (SCFC) combines $\mathrm{Fe}^{2+}$ with sirohydrochlorin forms siroheme (Bali et al. 2014). Disorganization in biosynthesis pathway of siroheme will induce the accumulation of some light-sensitive intermediates from chlorophyll pathway and then lead to reactive oxygen species (ROS) synthesis (Tripathy et al. 2010). Siroheme plays a crucial part in the reduction of nitrate and sulfate as a kind of accessorial factor. Since plants can utilize ammonium nitrogen and sulfur amino acid, instead of nitrate and sulfate directly from soil, the $\mathrm{Fe}^{2+}$ that chelated in the center of siroheme is capable of assisting the electronation of reduction of nitrate and sulfate (Hu et al. 2015; Garai et al. 2016).

\section{Heme}

It is worth mentioning that heme and chlorophyll share common synthesizers on the pathway from Uro III to protoporphyrin IX (Proto IX) (Fig. 2) (Akram and Ashraf 2013). Uro III casts off carboxyl group and turns to coproporphyrinogen III (CPG III), which catalyzed by uroporphyrinogen III decarboxylase (UROD). Coproporhyrinogen III oxidase (CPOX) converts CPG III into protoporphyrinogen IX (Protogen IX), and then protoporphyrinogen IX oxidase (PPOX) extracts six electrons of Protogen IX to form Proto IX (Nagahatenna et al. 2015).
Fig. 2 The downstream metabolism of ALA and regulatory factors among metabolic pathway. ALA is the common precursor of chlorophyll, heme and siroheme. Moreover, feedback inhibition effect plays an important regulative role in the pathway, where the pathway is associated with the positive regulators, like GUN4 and FHY3/FAR1 proteins; and negative regulator, like FLU protein

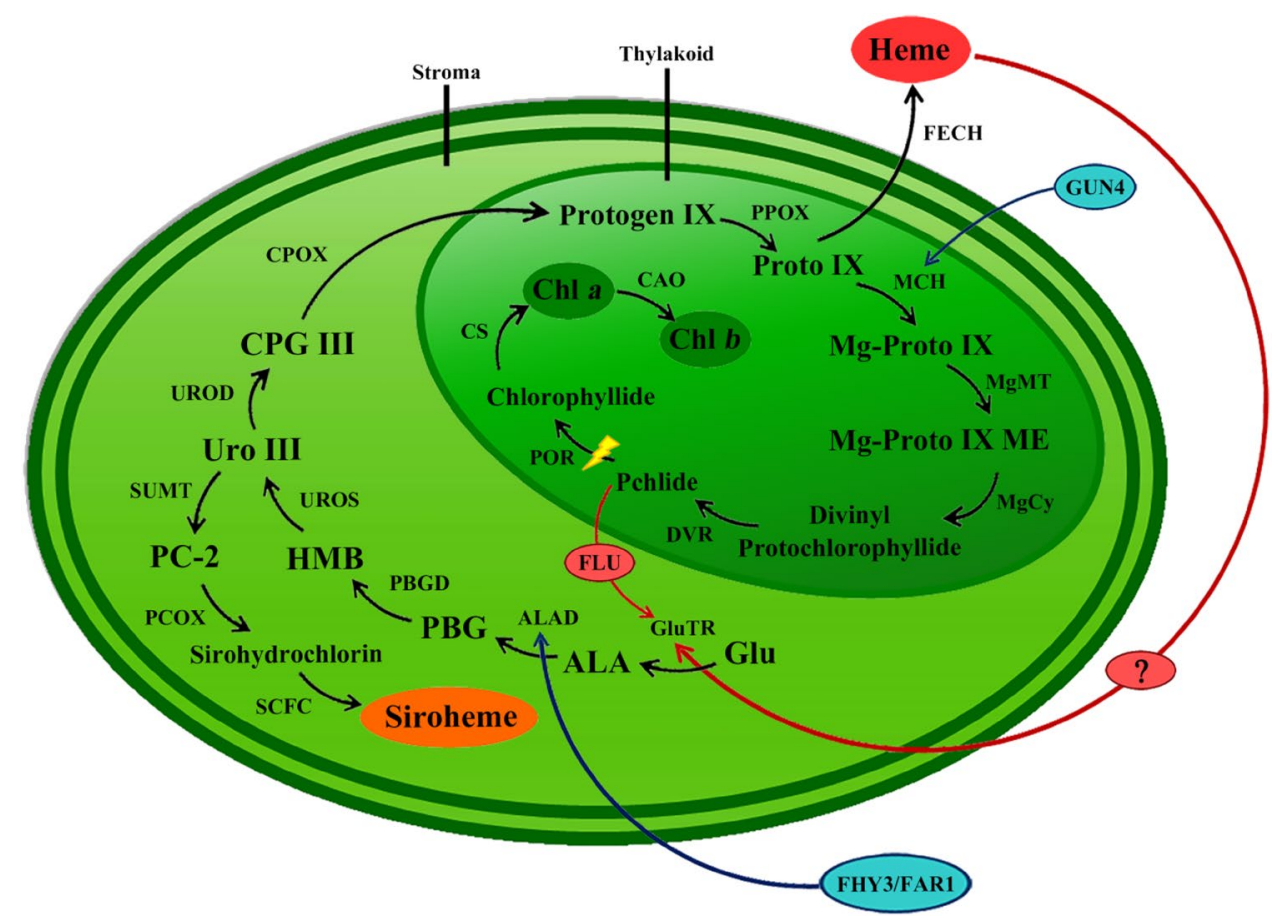


Ferrochelatase (FECH), encoded by $\mathrm{CsFeCl}, \mathrm{CsFeC2}$ genes, is the key enzyme in heme biosynthetic branch, and these genes are correlated with photosynthetic and nonphotosynthetic tissues in plants (Fig. 2) (Suzuki et al. 2002). FECH chelates $\mathrm{Fe}^{2+}$ into the porphyrin ring of Proto IX molecule to create heme (Dailey and Meissner 2013). The appearance of heme is correlated to the main post-translational feedback regulatory of GluTR as mentioned earlier, but the particular mechanism of GluTR inhibition by heme have not been evaluated yet (Apitz et al. 2014). Heme is an essential functional molecule which participates in many physiological reactions. In human and animal, heme is responsible for oxygen transfer and metabolism. Simultaneously, heme takes part in electron transfer and secondary metabolism within higher plants (Espinas et al. 2012). Heme can also be oxidized by heme oxygenase (HO), which will transform heme into $\mathrm{CO}$, free iron $\left(\mathrm{Fe}^{2+}\right)$, and biliverdin (BV) (Kwon et al. 2011). Among the offspring, BV will turn to bilirubin (BR), an intracellular potent antioxidant, under the catalyzing effect of $\mathrm{BV}$ reductase. Moreover, $\mathrm{CO}$ plays a critical role as signaling molecule and participates in regulating against various abiotic threats to plants (Wang and Liao 2016).

\section{Chlorophyll}

Chlorophyll is created by another branch which starts at Proto IX (Fig. 2). What activates the chelation reaction is the key enzyme in chlorophyll biosynthesis known as Mg-chelatase $(\mathrm{MCH})$, which can install $\mathrm{Mg}^{2+}$ into Proto IX, and give Mgprotoporphyrin IX (Mg-Proto IX) (Sobotka 2014). MCH consists of three subunits, ChlH, ChlI and ChlD in higher plants (Richter and Grimm 2013). Among these, it is ChlH that is primarily responsible for catalytic action of $\mathrm{MCH}$. Proved by research in the chlorophyll-deficient mutant of Chlamydomonas reinhardtii, the levels of mRNA and protein output of $\mathrm{ChlH}$ are both increased while ChlI and ChlD remained unalterable from dark condition to light (Chekounova et al. 2001). Then, Mg-protoporphyrin IX methyltransferase (MgMT) devolves a methyl group from $S$-adenosylL-methionine to Mg-Proto IX, giving Mg-protoporphyrin IX monomethyl ester (Mg-Proto IX ME) (Nguyen et al. 2016). Followed by Mg-protoporphyrin IX monomethyl ester cyclase $(\mathrm{MgCy})$, the reaction merges atomic oxygen $(\mathrm{O})$ to $\mathrm{Mg}$-Proto IX ME and creates 3,8-divinyl protochlorophyllide. In the next step, divinyl protochlorophyllide is deoxidized to form Pchlide, which is catalyzed by divinyl chlorophyllide 4-vinyl reductase (DVR) (Chen 2014). After that, under the existance of protochlorophyllide oxidoreductase (POR), chlorophyllide is formed. The last procedure of chlorophyll branch is promoted by chlorophyll synthase (CS) and thus, eventually creating chlorophyll $a(\mathrm{Chl} a$ ) (Akram and Ashraf 2013). In addition, Chl $a$ can be converted into chlorophyll $b(\mathrm{Chl} b)$ with the catalytic condition provided by chlorophyllide $a$ oxygenase (CAO) (Kunugi et al. 2013).

\section{Regulation mechanism on the pathway}

POR is one of the key reductases in this pathway, and it is a light-dependent enzyme in higher plants (Nickelsen et al. 2011). Inhibition of POR under dark condition causes the accumulation of Pchlide instantaneously, and then ALA synthesis is down-regulated, since there is a feedback regulation mechanism between ALA and Pchlide synthesis (Richter et al. 2010). Another negative feedback regulator is the FLU protein in plastid membranes; it has been proposed to have a synergetic role for chlorophyll branch, similar to the function of heme in Fe-branch (Kauss et al. 2012). GluTR is the effecting target of protein FLU (Zhang et al. 2015b). In barley, the $f l u$ ortholog mutant tigrina $d^{12}$, which unmakes ALA synthesis from dark-suppression, accumulated Pchlide under dark condition (Richter et al. 2010; Lee et al. 2003). The excessive accumulation of Pchlide led to the death of the plants after being illuminated, since substantial Pchlide produced massive active oxygen by light-motivated and seriously damaged chloroplast. This feedback regulation mechanism in higher plants is conducted to adapt to dark environments and protect plant tissue from peroxidative damage. Synergistically, lowering GluTR content by embedding HEMA-RNA-interference (RNAi) gene into tobacco (Nicotiana tabacum L.), resulted in the decline of $\mathrm{MCH}$ and $\mathrm{FECH}$ activities, causing the diminution of chlorophyll and heme content, respectively, as the transcript levels of these remained unchanged (Hedtke et al. 2007).

One more regulator to intermediates in this pathway is the GUN4 protein (Fig. 2). GUN4 has positive regulation roles in chlorophyll biosynthesis as it binds with intermediates (e.g. Proto IX, Mg-Proto IX and Mg-Proto IX ME) and enhances MCH activity (Fig. 2) (Yurina et al. 2012). Overexpression of Arabidopsis GUN4 protein in tobacco revealed general stimulation of tetrapyrrole biosynthesis, including the levels of chlorophyll, heme, Proto IX, and Mg-porphyrins and the activity of $\mathrm{MCH}$, compared with the wild-type tobacco (de Menezes Daloso et al. 2014). Besides, transcription factors like Far-red Elongated Hypocotyl 3 (FHY3) and Far-red Impaired Response 1 (FAR1) have positive regulative role to chlorophyll biosynthesis since they can bind and activate the expression of HEMB (encodes ALAD) (Tang et al. 2012).

\section{Effects of ALA on plant physiology and growth process}

At present, ALA is not only a metabolic intermediate in botany, but also a growth regulator in plant cultivation. ALA is regarded as a plant growth promoting hormone since it was 
found to regulate growth and development of higher plants by many researchers. ALA regulates plant growth and development in many ways and shows a concentration-dependent manner which will be discussed in detail below (Table 1).

\section{Seed germination}

The germination of seeds can be boosted by plant hormone (e.g. gibberellin) and signaling molecule (e.g. $\mathrm{CO}, \mathrm{H}_{2} \mathrm{~S}$ ), resulting in the enhancement of germination percentage (Oracz et al. 2011; Amooaghaie et al. 2015; Wang et al. 2012). It is analogical that nearly all those stimulative factors are provided with dose-dependent manner. Equally, as a potential plant growth regulator, ALA also accelerates seed germination in a dose-dependent manner. Research showed that $1 \mathrm{mg} / \mathrm{L}$ ALA greatly promoted the final germination percentage of Elymus nutans seeds and enhanced the respiration under cold condition $\left(5^{\circ} \mathrm{C}\right)$, however, high level of ALA $(25 \mathrm{mg} / \mathrm{L})$ inhibited germination (Fu et al. 2014). Meanwhile, the different concentrations of ALA affected distinct germinating indices. Under low-temperature stress $\left(15^{\circ} \mathrm{C}\right)$, the final germination percentage of Capsicum annиит seeds reached the maxim under $25 \mathrm{mg} / \mathrm{L}$ ALA condition while
$10 \mathrm{mg} / \mathrm{L}$ ALA treatment made the germination rate reach the highest value (Korkmaz and Korkmaz 2009). On the contrary, $0.5 \mathrm{mM}$ ALA in germination medium prevented seed germination of Chinese cabbage (Brassica rapa L.) (Chon 2003).

\section{Vegetative growth}

Except for the promotive role it plays in seed germination, ALA also play effective role in plant growth. For example, ALA (30 mg/L) ameliorated the osmotic potential and relative water content (RWC) of oilseed rape (B. napus L.) by foliar applying to seedlings (Naeem et al. 2011). Exogenous ALA produced by Rhodopseudomonas palustris strains, one kind of purple nonsulfur bacteria which could secrete ALA $(2.67 \mu \mathrm{M})$, distinctly increased the relative root growth and dry weight of rice under $\mathrm{NaCl}$ stress (Nunkaew et al. 2014). Moreover, $2 \mathrm{mg} / \mathrm{L}$ ALA applied in the germination stage of B. napus as a pretreatment, resulted in obviously enlarging on leaf length, leaf width, radical and hypocotyls length and root biomass under $100 \mathrm{mM} \mathrm{Cd}$ condition (Ali et al. 2013a). Besides, plant tissue culture is an indispensable way in plant science and it is not only for callus induction, rapid

Table 1 Overview of ALA—regulated physiology and growth process in plants

\begin{tabular}{|c|c|c|c|c|c|c|}
\hline Physiological process & Plant species & Abiotic stress & Application mode & ALA concentration & Regulation & Reference \\
\hline \multirow[t]{3}{*}{ Seed germination } & Brassica rapa $\mathrm{L}$. & Non-stress & Germination medium & $0.5 \mathrm{mM}$ & - & Chon (2003) \\
\hline & Capsicum аппиит $\mathrm{L}$. & Cold & Germination medium & $10,25 \mathrm{mg} / \mathrm{L}$ & + & $\begin{array}{l}\text { Korkmaz and Korkmaz } \\
\text { (2009) }\end{array}$ \\
\hline & Elymus nutans L. & Cold & Germination medium & $\begin{array}{l}1 \mathrm{mg} / \mathrm{L} \\
25 \mathrm{mg} / \mathrm{L}\end{array}$ & $\begin{array}{l}+ \\
-\end{array}$ & Fu et al. (2014) \\
\hline \multirow[t]{11}{*}{ Vegetative growth } & Brassica napus L. & Cadmium & Seed presoaking & $2 \mathrm{mg} / \mathrm{L}$ & + & Ali et al. (2013a) \\
\hline & Hordeum vulgare $\mathrm{L}$. & Non-stress & Seed presoaking & $5,10 \mathrm{mM}$ & - & Kuk et al. (2003) \\
\hline & Ixeris dentate Thunb. & Non-stress & Foliar spray & $3.9 \mathrm{mM}$ & - & \\
\hline & Laminaria japonica & Non-stress & Induction medium & $500 \mathrm{mg} / \mathrm{L}$ & + & Tabuchi et al. (2009) \\
\hline & $\begin{array}{l}\text { Malachium aquati- } \\
\text { cum } \mathrm{L} .\end{array}$ & Non-stress & Foliar spray & $100 \mathrm{mg} / \mathrm{L}$ & - & Xu et al. (2015) \\
\hline & Medicago sativa $\mathrm{L}$. & Non-stress & Seed presoaking & $8 \mathrm{mM}$ & - & Chon (2003) \\
\hline & Oryza sativa $\mathrm{L}$. & Salt & Root presoaking & $2.67 \mu \mathrm{M}$ & + & Nunkaew et al. (2014) \\
\hline & Oryza sativa $\mathrm{L}$. & Non-stress & Foliar spray & $5 \mathrm{mM}$ & - & Phung and Jung (2014) \\
\hline & Phoenix dactylifera $\mathrm{L}$. & Non-stress & Foliar spray & $50,100 \mathrm{mg} / \mathrm{L}$ & + & $\begin{array}{l}\text { Awad and Al-Qurashi } \\
\text { (2011) }\end{array}$ \\
\hline & Setaria viridis L. & Non-stress & Foliar spray & $1.6 \mathrm{mM}$ & - & Kuk et al. (2003) \\
\hline & Taxus cuspidata Sieb. & Non-stress & Suspension medium & $7.6 \mu \mathrm{M}$ & + & Yamamoto et al. (2015) \\
\hline \multirow[t]{4}{*}{ Fruit coloring } & Litchi chinensis Sonn. & Non-stress & Fruit spray & $80 \mathrm{mg} / \mathrm{L}$ & + & Feng et al. (2015) \\
\hline & $\begin{array}{l}\text { Malus } \times \text { domestica } \\
\text { Borkh. }\end{array}$ & Non-stress & Fruit spray & $150-300 \mathrm{mg} / \mathrm{L}$ & + & Xie et al. (2013) \\
\hline & $\begin{array}{l}\text { Malus } \times \text { domestica } \\
\text { Borkh. }\end{array}$ & Non-stress & Fruit spray & $300 \mathrm{mg} / \mathrm{L}$ & + & Chen et al. (2015) \\
\hline & $\begin{array}{l}\text { Prunus persica L. } \\
\text { Batsch }\end{array}$ & Non-stress & Fruit spray & $200,400 \mathrm{mg} / \mathrm{L}$ & + & Ye et al. (2017) \\
\hline
\end{tabular}

The symbol + shows positive regulation and - shows negative regulation 
propagation (micropropagation) and chemical production, but it can also be applied in selecting and breeding of crops, in order to choose elite cultivars or improve resistance (Yukimune et al. 2000; Taghizadeh et al. 2015). The use of ALA, as a growth promoter, promoted callus induction and micropropagation of Vigna unguiculata L., callus propagation of Laminaria japonica and paclitaxel histological production of Taxus cuspidata (Bindu and Vivekanandan 1998; Tabuchi et al. 2009; Yamamoto et al. 2015). Moreover, seed potato breeding and the growth of tissue culture-derived Phoenix dactylifera $\mathrm{L}$. seedling were promoted by ALA (Zhang et al. 2006; Awad 2008; Awad and Al-Qurashi 2011).

The application of exogenous ALA to higher plants revealed dose-effect, that is, relative high concentration of ALA usually caused damage to plants. For example, low concentration of ALA $(0.05-0.5 \mathrm{mM})$ increased the growth of five cultivars of barley $(H$. vulgare $\mathrm{L}$.) in different degrees, however, it retarded the growth of barley at a high level (5, $10 \mathrm{mM}$ ) (Kuk et al. 2003). Moreover, $8 \mathrm{mM}$ ALA solution used for seed treatment inhibited plant height of seedling of alfalfa (Medicago sativa L.) (Chon 2003). White necrosis occurred on rice seedling leaves when the plants were sprayed with $5 \mathrm{mM}$ ALA, and MDA content was increased (Phung and Jung 2014). The reason for high ALA concentration causing plant damage is that increase of endogenous ALA level will lead to up-regulation of photosensitive intermediates downstream of ALA metabolism, and over-accumulation of these will lead to photo-oxidation damage in plant tissue. This mechanism makes ALA function as a nontoxic herbicide for practical application in agriculture (Papenbrock and Grimm 2001; Sasaki et al. 2002; Dayan and Duke 2014). The growth of a major weed of rape, crickweed (Malachium aquaticum L.), was suppressed by $100 \mathrm{mM}$ ALA which caused oxidative stress and chloroplast ultrastructure disorder (Xu et al. 2015). In addition, monocotyledon weed Setaria viridis and dicotyledon weed Ixeris dentate were sensitive to exogenous ALA, and the shoot fresh weight of these plants were significantly inhibited (Kuk et al. 2003).

\section{Fruit coloring}

The study of ALA in regulating the color of fruits is a relative new research area. According to studies, the application of ALA is beneficial to fruit coloration and maturity of higher plants. For example, the fresh weight, fruit color and ${ }^{\circ}$ Brix value of berries were enhanced by foliage application of $100 \mathrm{mg} / \mathrm{L} \mathrm{ALA}$, at flowering period in a 2-year-old grapevines plants (Vitis vinifera L.) (Watanabe et al. 2006). During fruit growth and maturation, the coloring of pannexterna is due to anthocyanin biosynthesis and accumulation, which can be affected by light and plant hormone (including abscisic acid and naphthaleneacetic acid) (Jeong et al. 2004; Vimolmangkang et al. 2014; Li et al. 2016). Genes in 'Fuji' apple skin, including enzyme genes ( $P a l$, $C h s$ and $U f g t)$ and transcription factors $(M y b, b H L H$ and $W d 40$ ) related to anthocyanin biosynthesis, were all upregulated by ALA solution sprayed on the surface of fruits (Xie et al. 2013; Chagné et al. 2016). Moreover, application of exogenous ALA on developing fruit also improved the anthocyanin accumulation of apple (Malus $\times$ domestica Borkh.) and Litchi chinensis Sonn. peel (Chen et al. 2015; Feng et al. 2015). The molecular mechanism of ALA enhances anthocyanin accumulation in fruit skin might be an ALA-induced up-regulation of MdMADS1, a developmental transcription regulator of fruit ripening; because overexpressed MdMADS1 in apple (Malus $\times$ domestica Borkh.) calli resulted in increasing anthocyanin content (Feng et al. 2016). Moreover, in fruit of Prunus persica L. Batsch, six structural genes (CHS, CHI, F3H, DFR, LDOX and UFGT) and two transcription factors (MYB10 and WD40) involved in anthocyanin biosynthesis were all evidently upregulated by ALA treatment (200, $400 \mathrm{mg} / \mathrm{L})$ (Ye et al. 2017).

\section{Role of ALA in plants under abiotic stresses}

The application of ALA against various abiotic stresses has been extensively reported. Details of the role of ALA against the adverse effects of herbicide, shade, cold, drought, salt and heavy metals is summarized in Table 2. However, the physiological mechanisms of ALA in stress tolerance have not been adequately reported.

\section{Heightened photosynthesis}

Photosynthesis can be disorganized by environmental stresses which can lead to degradation of photosynthetic pigments, retardation of chlorophyll biosynthesis, reduction of light, change of gas-exchange characteristics, or inactivation of photosynthetic enzymes (Ashraf and Harris 2013). As a key precursor in the biosynthesis pathway of chlorophyll, ALA was reported to have promotive role in photosynthesis under stresses. For example, chlorophyll content was evidently increased by foliar application of ALA in leaves of pakchoi (Brassica campestris ssp. chinensis) and Ginkgo biloba plants (Memon et al. 2009; Feng et al. 2011). Abiotic stress caused damages to the configuration of chloroplastid in plants, including diminished chloroplast, swollen grana, dilations of the thylakoids, decreased starch and increased plastoglobules, etc (Paramonova et al. 2004; Ali et al. 2014a). Nevertheless, these damages were reversed through the application of ALA in B. napus, and chloroplast ultrastructures were recovered (Naeem et al. 2012; Gill et al. 2015). In addition, gas-exchange characteristics are important indexes for measuring plant photosynthetic capacity, 
Table 2 Overview of the promotive role of ALA under abiotic stress in plants

\begin{tabular}{|c|c|c|c|c|}
\hline Physiological process & Plant species & Abiotic stress & ALA-regulated index & Reference \\
\hline \multirow[t]{10}{*}{ Photosynthesis } & Brassica napus L. & Salt & $\begin{array}{l}\text { Chloroplast ultrastructure } \\
\text { Pigment content }\end{array}$ & Naeem et al. (2012) \\
\hline & Brassica napus L. & Cadmium & $\begin{array}{l}\text { Pigment content } \\
\text { Gas exchange parameters } \\
\text { Chloroplast ultrastructure }\end{array}$ & Ali et al. $(2013 a, b)$ \\
\hline & Brassica napus $\mathrm{L}$. & Drought & $\begin{array}{l}\text { Gas exchange parameters } \\
\text { Chlorophyll fluorescence }\end{array}$ & Liu et al. (2013) \\
\hline & Brassica napus $\mathrm{L}$. & Cadmium & $\begin{array}{l}\text { Chloroplast ultrastructure } \\
S O D, P O D, A P X, C A T, G R \text { expression }\end{array}$ & Gill et al. (2015) \\
\hline & Brassica napus L. & Salt & $\begin{array}{l}\text { Relative expression of GluTS, GluTR, } \\
A L A D \\
\text { Proto IX, Mg-Proto IX and Pchlide } \\
\text { content }\end{array}$ & Xiong et al. (2018) \\
\hline & Cassia obtusifolia $\mathrm{L}$. & Salt & $\begin{array}{l}\text { Chl content } \\
\text { Chlorophyll fluorescence parameters }\end{array}$ & Zhang et al. (2013) \\
\hline & Cucumis sativus $\mathrm{L}$. & Salt & $\begin{array}{l}\text { Relative expression of } H E M A 1, H E M H \text {, } \\
\quad C H L H, P O R \text { and } C A O\end{array}$ & Wu et al. (2018) \\
\hline & Phoenix dactylifera $\mathrm{L}$. & Salt & Chla/Chlb, Gs, $\mathrm{S}_{\mathrm{L}}$ & Youssef and Awad (2008) \\
\hline & Prunus persica L. Batsch & Salt & $\begin{array}{c}\text { Gas exchange parameters, proline, } \\
\text { soluble sugars, soluble proteins }\end{array}$ & Ye et al. (2016) \\
\hline & Zea mays $\mathrm{L}$. & Cold & RuBPCase and PEPCase activity & Wang et al. (2018) \\
\hline \multirow[t]{7}{*}{ Ions, nutrients uptake } & Beta vulgaris L. & Salt & $\begin{array}{l}\mathrm{N}, \mathrm{Na}^{+}, \mathrm{K}^{+} \text {content } \\
\mathrm{Na}^{+} / \mathrm{K}^{+} \text {ratio }\end{array}$ & Liu et al. (2014) \\
\hline & Brassica napus L. & Salt & $\mathrm{N}, \mathrm{P}, \mathrm{Ca}^{2+}, \mathrm{Na}^{+}, \mathrm{Zn}^{2+}, \mathrm{Fe}^{2+}$ content & Naeem et al. (2010) \\
\hline & Brassica campestris L. & Nutrient deficiency & $\begin{array}{l}\mathrm{N} \text { content, } \mathrm{NR} \text { activity } \\
N R \text { expression }\end{array}$ & Wei et al. (2012) \\
\hline & Brassica napus L. & Lead & $\begin{array}{l}\text { Ion uptake capability } \\
\text { AsA, GSH, ROS, MDA content }\end{array}$ & Ali et al. (2014b) \\
\hline & Helianthus annuus L. & Salt & $\begin{array}{l}\mathrm{Na}^{+}, \mathrm{Cl}^{-}, \mathrm{K}^{+}, \mathrm{Ca}^{2+} \text { content } \\
\mathrm{K}^{+} / \mathrm{Na}^{+} \text {ratio }\end{array}$ & Akram and Ashraf (2011) \\
\hline & Helianthus annuus L. & Salt & $\mathrm{P}, \mathrm{Na}^{+}, \mathrm{Cl}^{-}, \mathrm{K}^{+}, \mathrm{Ca}^{2+}$ content & Akram et al. (2011) \\
\hline & Phoenix dactylifera $\mathrm{L}$. & Salt & $\begin{array}{l}\mathrm{N}, \mathrm{P}, \mathrm{K}^{+}, \mathrm{Na}^{+} \text {content } \\
\mathrm{K}^{+} / \mathrm{Na}^{+} \text {ratio }\end{array}$ & Awad and Al-Qurashi (2011) \\
\hline \multirow[t]{9}{*}{ Antioxidant defense system } & Brassica napus L. & Drought & $\begin{array}{l}\text { ROS, MDA content } \\
\text { GSH/GSSG, ASA/DHA ratio } \\
P O D, C A T, G R \text { expression }\end{array}$ & Liu et al. (2011) \\
\hline & Brassica juncea $\mathrm{L}$. & Salt & $\begin{array}{l}\mathrm{H}_{2} \mathrm{O}_{2} \text {, MDA content } \\
\text { SOD, POD, CAT, APX, GR activity }\end{array}$ & Ahmad et al. (2012) \\
\hline & Brassica napus L. & Cadmium & $\begin{array}{l}\text { ROS, MDA content } \\
\text { CAT, SOD, POD, GR activity }\end{array}$ & Ali et al. $(2013 a, b)$ \\
\hline & Citrullus lanatus Thunb. & Shade & SOD, POD, APX activity & Sun et al. (2009) \\
\hline & Cucumis sativus $\mathrm{L}$. & Drought & $\begin{array}{l}\text { ROS, GSH content } \\
\text { GPX, GSH, DHAR activity }\end{array}$ & Li et al. (2011) \\
\hline & Cucumis sativus $\mathrm{L}$. & Salt & $\begin{array}{l}\text { SOD, CAT, GR, APX, DHAR, MDHAR } \\
\text { activity } \\
C A T, A P X, G R \text { expression }\end{array}$ & Zhen et al. (2012) \\
\hline & Glycine $\max \mathrm{L}$. & Chilling & $\begin{array}{l}\text { MDA, ROS content } \\
\text { CAT, HO- } 1 \text { activity } \\
H O-1 \text { expression }\end{array}$ & Balestrasse et al. (2010) \\
\hline & Oryza sativa $\mathrm{L}$. & Cold & SOD, POD, APX, GPX activity & Sheteiwy et al. (2017) \\
\hline & Solanum lycopersicum $\mathrm{L}$. & Cold & $\begin{array}{l}\mathrm{H}_{2} \mathrm{O}_{2} \text { content } \\
\text { GSH/GSSG, ASA/DHA ratio } \\
\text { APX, GR, CAT, SOD, MDHAR, DHAR } \\
\quad \text { activity }\end{array}$ & Liu et al. (2018) \\
\hline \multirow[t]{4}{*}{ Osmoregulation } & Cucumis sativus L. & Heat & Proline, soluble sugar content & Zhang et al. (2012) \\
\hline & Ficus carica Linn. & Waterlog & leaf RWC & An et al. (2016) \\
\hline & Helianthus annuus L. & Salt & $\begin{array}{l}\text { Leaf osmotic potential }(\Psi \mathrm{s}), \mathrm{RWC} \\
\text { Proline, GB, soluble protein content }\end{array}$ & Akram et al. (2012) \\
\hline & Triticum aestivum $\mathrm{L}$. & Drought & $\begin{array}{l}\text { Proline, GB content } \\
\text { water-use efficiency (WUE) }\end{array}$ & Kosar et al. (2015) \\
\hline
\end{tabular}


which can be disordered under external stress generally (Piao et al. 2008). Under $100 \mathrm{mM} \mathrm{NaCl}$ stress, $200 \mathrm{mg} / \mathrm{L}$ ALA treated peach (P. persica L.) seedlings showed significantly ameliorated in net photosynthetic rate (Pn), stomatal conductance (Gs), transpiration rate (Tr) and intercellular $\mathrm{CO}_{2}$ concentration $(\mathrm{Ci})$, the salt tolerance of peach plants was enhanced (Ye et al. 2016). Regardless of the application method used, ALA enhanced gas exchange capacity severally in date palm ( $P$. dactylifera $\mathrm{L}$.) and oilseed rape (B. napus L.) under salinity and cadmium stress (Youssef and Awad 2008; Ali et al. 2013b). Moreover, the application of ALA improved chlorophyll fluorescence parameters (including photochemical efficiency of photosystem II (Fv/ $\mathrm{Fm})$, photochemical efficiency $\left(\mathrm{Fv}^{\prime} / \mathrm{Fm}^{\prime}\right)$, PSII actual photochemical efficiency (ФPSII), and photochemical quench coefficient (qP)) in Cassia obtusifolia L. under salt stress were, but the non-photochemical quenching coefficient (NPQ) was decreased, indicating that photochemical activity of PSII can be repaired by ALA (Zhang et al. 2013). In addition, under Cd stress, the photosynthetic fluorescence parameters were improved by ALA application (Ali et al. 2015). In the presence of competitor (methyl viologen) and inhibitor (3-(3,4-dichlorophenyl)-1,1-dimethyl urea) for electron transport, $150 \mu \mathrm{M}$ ALA treatment on strawberry (Fragaria ananassa Duch.) root could help leaves to keep relative high electron transfer efficiency in PSI (Sun et al. 2016). Indicating that the improvement of photosynthesis by ALA in plants was not only related to PSII, but also to PSI and electron transfer chain. In addition, the application of ALA results in increases in the content of endogenous ALA. As elucidated in the research of oilseed rape, exogenous ALA enhanced the tetrapyrrol biosynthesis pathway and the content of chlorophyll (Liu et al. 2016). The relative expression of upstream gene of ALA, GluTS, was upregulated by exogenous ALA (30 mg/L) and contents of intermediates (Proto IX, Mg-Proto IX and Pchlide) were increased in B. napus L. under $200 \mathrm{mM} \mathrm{NaCl}$ stress (Xiong et al. 2018). Moreover, under $50 \mathrm{mM} \mathrm{NaCl}$ stress, spraying ALA on cucumber leaves significantly reversed the depression of chlorophyll biosynthesis, up-regulated the expression level of genes related to $\mathrm{Mg}$-branch, including $\mathrm{CHLH}, \mathrm{POR}$ and $C A O$ (Wu et al. 2018). It indicated that the primary fluorescence of chlorophyll and the electron transfer rate of light harvesting pigment will be enhanced, and ultimately result in the promotion of photosynthesis in photosynthetical system. Besides, exogenous ALA can also benefit for carbon assimilation stage. For example, activities of ribulose-1,5-bisphosphate carboxylase (RuBPCase) and phosphoenolpyruvate carboxylase (PEPCase) in low-temperature $\left(14 / 5{ }^{\circ} \mathrm{C}\right.$, day/ night) treated maize (Z. mays L.) seedlings were enhanced through spraying $0.15 \mathrm{mM}$ ALA (Wang et al. 2018).

\section{Amended ions and nutrients uptake}

Abiotic stresses lead to ion and nutrient imbalance in plants in general, under higher saline condition, there must have lower osmotic potential in rhizosphere environment, which breaks the original ionic equilibrium in plants (Zhu 2001). Salinity increases the concentration of $\mathrm{Na}^{+}$and $\mathrm{Cl}^{-}$in plant tissue but the content of $\mathrm{K}^{+}$and $\mathrm{Ca}^{2+}$ reduces. However, the application of ALA could restore the ionic balance, in sunflower (Helianthus annuus L.) and B. napus (Akram and Ashraf 2011; Naeem et al. 2012). Under normal growth condition, plants usually keep a relatively higher $\mathrm{K}^{+} / \mathrm{Na}^{+}$, while high extracellular $\mathrm{Na}^{+}$concentration will bring a large $\mathrm{Na}^{+}$electrochemical potential gradient and then cause ion stress ( $\mathrm{Su}$ et al. 2015). Exogenesis ALA alleviated the salinity stress of creeping bentgrass and promoted its growth and organic acids accumulation, which was mainly due to the suppression of ion toxicity caused by $\mathrm{Na}^{+}$(Yang et al. 2014). Application of ALA increased P content in seeds and leaves under $\mathrm{NaCl}$ stress in date palm $(P$. dactylifera $\mathrm{L}$.) and sunflower (Awad and Al-Qurashi 2011; Akram et al. 2011). Moreover, under sodium and lead toxicity, absorption of other macro- and micro-elements including $\mathrm{Ca}, \mathrm{Mg}, \mathrm{Mn}$ and $\mathrm{Cu}$ was significantly improved by ALA, and the stressinduced damages were ameliorated (Naeem et al. 2010; Liu et al. 2014; Ali et al. 2014b). Furthermore, nutritive material uptake, such as sulfate or nitrate, could be strengthened by application of ALA. Nitrogen metabolism of watermelon seedling, which was affected by salinity, could be regulated through by ALA which significantly increased the activities of nitrate reductase (NR), glutamine synthetase (GS), glutamate synthase (GOGAT), and glutamate dehydrogenase (GDH) (Chen et al. 2017). In plants under nutrient deficiency condition, applied-ALA increased the transcription and translation level of NR or SULTR (a gene related to sulfur transport assimilation) (Maruyama-Nakashita et al. 2010; Wei et al. 2012; Beyzaei et al. 2014).

Coupled with the biosynthesis of siroheme discussed above, a hypothesis can be set here that nitrogen and sulfur uptake might be strengthened by increasing level of siroheme through application of ALA, since siroheme is a crucial part of accessorial factor in reduction actions of nitrate and sulfate in plants. This can be a potential justification for studying the regulative mechanism of ALA towards nutrition uptake of plants.

\section{Enhanced antioxidant defense system}

The production of ROS in plants at typical growth condition is a normal physiological phenomenon, and ROS, to some extent, have connection with cell proliferation and differentiation (Gechev and Hille 2012). But in the process of stress, more ROS will appear and accumulate in chloroplast, 
mitochondria, and peroxisome, then cause damage to carbon-carbon double bond (s) of polyunsaturated fatty acids (PUFAs) in membrane lipid, and bring a secondary product, malondialdehyde (MDA), which is also an important index to determine degree of peroxidation (Choudhury et al. 2016; Dietz et al. 2016; Huang et al. 2016; Rodríguez-Serrano et al. 2016; Ayala et al. 2014). Treatments with ALA suppressed the increasing of $\mathrm{H}_{2} \mathrm{O}_{2}$ and MDA (or TBARS) under abiotic stress by enhancing enzymes activities of antioxidant defense system (Balestrasse et al. 2010; Ahmad et al. 2012). Under shade stress and $\mathrm{Cd}$ toxicity, the activities of superoxide dismutase (SOD), catalase (CAT) and peroxidase (POD) were increased in watermelon seedlings and oilseed rape by ALA (Sun et al. 2009; Ali et al. 2013a). In the research of rice seedlings under cold stress $\left(10^{\circ} \mathrm{C}\right)$, the activities of SOD, POD, ascorbate peroxidase (APX) and glutathione peroxidase (GPX) were boosted by soaking ALA ( $8.5 \mathrm{mM})$ during seed germination (Sheteiwy et al. 2017). Studies toward genome level suggested that $1 \mathrm{mg} / \mathrm{L}$ ALA up-regulated the expression of $P O D, C A T$, $A P X$ of oilseed rape (B. napus L.) under water-deficit condition and cucumber ( $C$. sativus L.) seedlings under $\mathrm{NaCl}$ condition (Liu et al. 2011; Zhen et al. 2012). Another antioxidant mechanism which mainly scavenges $\mathrm{H}_{2} \mathrm{O}_{2}$ in plants is known as ascorbate-glutathione (AsA-GSH) cycle, consists of enzymes and non-enzymatic antioxidants ( $\mathrm{Li}$ et al. 2010). The application of ALA could enhance reduced/oxidized glutathione ratio (GSH/GSSG) and reduced/oxidized ascorbic acid ratio (AsA/ DHA) via strengthening the activities of glutathione reductase (GR) and dehydroascorbate reductase (DHAR) (Nishihara et al. 2003; Li et al. 2011; Liu et al. 2018).

Besides, it is feasible to relate these results with one of the branches of ALA metabolic pathway, which is the Febranch. For the oxidation resisting role of BR, a decomposition product of heme, it could inhibit protein oxidation in vitro in the presence of a variety of oxidants including superoxide and hydroxyl radicals (Wegiel et al. 2014; Xie et al. 2015). The heme content was increased significantly by ALA in maize (Z. mays L.) under non-stressful condition (Yonezawa et al. 2015). Moreover, in a research of transgenic rice, which overexpressed the $\mathrm{FECH}$ gene of Bradyrhizobium japonicum, resulted in increasing activity of $\mathrm{FECH}$, raising content of heme and enhancing tolerance of oxidative stress (Kim et al. 2014). Therefore, this may provide a kind of new thought to explain the promotive roles of ALA towards oxidative stress resistance.

\section{Promoted osmoregulation}

ALA pretreatment before waterlogging stress promoted RWC in Ficus carica Linn. leaves (An et al. 2016). In spring wheat (Triticum aestivum L.) under drought stress, content of an osmotic adjustment substance, glycine betaine (GB), increased by foliar application of ALA (Kosar et al. 2015).
Also, contents of proline, soluble sugar and soluble protein increased in plants treated with ALA and improved tolerance against salinity or heat induced osmotic stress (Zhang et al. 2012; Akram et al. 2012). Furthermore, amylase activity and expression of RsBAMY1 protein were up-regulated by ALA in radish taproot (Raphanus sativus L.); it might suggest that ALA increased osmotic adjustment substances by strengthening starch-degrading enzymes (Hara et al. 2011). What was interesting was the considerably accumulation of proline and inhibition of endogenous ALA biosynthesis under severe $\mathrm{NaCl}$ stress. Since proline and ALA have a common precursor, glutamate, in both of their synthetic routes, the researchers conjectured that the metabolic pathway of glutamic acid may converted from ALA-synthesizing to the proline synthesis pathway, which enhanced the proline accumulation against osmotic disturbance (Averina et al. 2010).

Beyond the biosynthesis of proline, enhanced photosynthesis will produce more carbohydrate in plant, and the decomposition of carbohydrates will provide numerous osmotic adjustment substances (such as soluble sugar) and energy to react against abiotic stresses.

\section{Manipulation of relative genes in ALA pathway}

In recent years, molecular breeding has become more popular in plant research to promote and modify crops. In the light of the regulative role of exogenous ALA in plants response to various environmental stresses, ALA-related genes manipulation could theoretically regulate the tetrapyrrol biosynthesis or enhance plant stress tolerance.

The structure and sequence of HEMA, which encodes 5-aminolevulinic acid synthase (ALAS), was first studied in B. japonicum in 1987 (McClung et al. 1987). However, few reports are available on transgenic plants with manipulative genes of ALA (Table 3). ALAS gene from B. japonicum overexpressed in Oryza sativa showed an increase of contents of ALA, Proto IX, and protochlorophyllide, and then caused photodynamic damage (Jung et al. 2004b, 2008a). Similarly, A. thaliana mutant with overexpressed $H E M B 1$, which encodes ALAD, revealed dysgenesis, and when knocked down the endogenous $H E M B 1$ expression in wild type, the seedling cotyledons turned white or pale since they could not synthetize chlorophyll effectively (Tang et al. 2012). Human mitochondrial PPOX gene (PPO) overexpressed in transgenic rice plants revealed severe necrotic spots on leaves and growth retardation since tetrapyrrole overaccumulated in the plant (Jung et al. 2008b). Activity of PPOX in transgenic tobacco (N. tabacum L.) overexpressed plastid $P P O X$ of Arabidopsis was enhanced and was not affected by $300 \mathrm{nM}$ acifluorfen stress, this indicated that toxic tetrapyrrole was metabolized efficiently under herbicide stress (Lermontova and Grimm 2000). Seeds of 
transgenic rice with overexpressing PPOX gene from Myxococcus xanthus protox germinated normally under $500 \mu \mathrm{M}$ oxyfluorfen stress but the wildtype seeds could not germinate under $1 \mu \mathrm{M}$ oxyfluorfen (Jung et al. 2004a). Transgenic rice plants with overexpressed $M$. xanthus PPOX gene were characterized by more stable Fv/Fm, lower concentration of $\mathrm{H}_{2} \mathrm{O}_{2}$ and less MDA compared with the wild-type under incubated oxyfluorfen stress $(0.1-10 \mu \mathrm{mol} / \mathrm{L})$, and this indicated that the transgenic lines of rice had enhanced resistance (Jung and Back 2005). Transgenic Arabidopsis plants with yeast ALAS gene (YHeml) showed higher resistance when exposed to $\mathrm{NaCl}$ stress, their germination, growth, chlorophyll and heme contents were much higher than the wild type (Zhang et al. 2010). Besides, in the study of transgenic rice, which overexpressed B. japonicum FECH gene, resulted in increasing activity of $\mathrm{FECH}$, then raising content of heme and enhancing the tolerance of oxidative stress (Kim et al. 2014).

Besides, in microbial production field, ALA extracellular accumulation of Escherichia coli was actualized by inserting HEMA gene from B. japonicum (Choi et al. 1999). In addition, the up-regulation of $H E M D$ and $H E M F$ (encoding
UROS and CPOX respectively) were propitious to ALA accumulation in E. coli (Zhang et al. 2015a).

\section{Conclusion and future perspective}

The yield reduction of crops and damage caused to plants as a result of climate change, which makes amelioration and improvement of stress tolerance in agricultural plants more important and an urgent issue in the twenty-first century. As an intermediate in vivo, ALA can be used in medical and agricultural fields (Fig. 3). Exogenous application of ALA is a relatively new among plenty of hormones, regulators or small signaling molecules. As a nontoxic compound, ALA can be synthesized in the metabolic pathway of plants, and as a common precursor of all tetrapyrrole, including chlorophyll, heme and siroheme (Fig. 3). Moreover, as an intermediary substance, the content of ALA affect metabolic pathway downstream and finally impact the outcomes. Simultaneously, feed-back regulation of downstream products regulates the biosynthesis of ALA in an opposite manner. There are regulatory factors on the pathway, including

Table 3 Genetic manipulation towards ALA-related genes in plants

\begin{tabular}{|c|c|c|c|c|c|}
\hline Plant species & Target gene & Gene source & Regulation & Effect & Reference \\
\hline Arabidopsis thaliana $\mathrm{L}$. & YHeml (encodes ALAS) & Saccharomyces cerevisiae & + & $\begin{array}{l}\text { Higher resistant to salt } \\
\text { stress than wild type plant }\end{array}$ & Zhang et al. (2010) \\
\hline Arabidopsis thaliana $\mathrm{L}$. & HEMB1 (encodes ALAD) & $\begin{array}{l}\text { Arabidopsis thaliana wild } \\
\text { type }\end{array}$ & - & Dysgenesis & Tang et al. (2012) \\
\hline Nicotiana tabacum $\mathrm{L}$. & $P P O X$ (encodes PPOX) & Arabidopsis thaliana $\mathrm{L}$. & + & $\begin{array}{l}\text { PPOX activity was } \\
\text { enhanced in transgenic } \\
\text { lines and acifluorfen } \\
\text { stress }(300 \mathrm{nM}) \text { did } \\
\text { not affect the activity } \\
\text { of PPOX in transgenic } \\
\text { plants }\end{array}$ & $\begin{array}{r}\text { Lermontova and } \\
\text { Grimm (2000) }\end{array}$ \\
\hline Oryza sativa $\mathrm{L}$. & $A L A S$ (encodes ALAS) & Bradyrhizobium japonicum & - & Photodynamic damage & Jung et al. (2004b) \\
\hline Oryza sativa $\mathrm{L}$. & $A L A S$ (encodes ALAS) & Bradyrhizobium japonicum & - & Photodynamic damage & Jung et al. (2008a) \\
\hline Oryza sativa $\mathrm{L}$. & $\mathrm{BjFeCh}$ (encodes FECH) & Bradyrhizobium japonicum & + & $\begin{array}{l}\text { Enhanced photosynthesis } \\
\text { and resistant to herbicide } \\
\text { stress }\end{array}$ & Kim et al. (2014) \\
\hline Oryza sativa $\mathrm{L}$. & $P P O$ (encodes PPOX) & Human & - & $\begin{array}{l}\text { Heme and chlorophyll con- } \\
\text { tents decreased; severe } \\
\text { necrotic spots on leaves } \\
\text { and growth retardation }\end{array}$ & Jung et al. (2008b) \\
\hline Oryza sativa $\mathrm{L}$. & $P P O X$ (encodes PPOX) & Myxococcus xanthus protox & + & $\begin{array}{l}\text { Seeds of the transgenic } \\
\text { rice germinated normally } \\
\text { under } 500 \mu \mathrm{M} \text { oxyfluor- } \\
\text { fen but wildtype seeds did } \\
\text { not germinate; transgenic } \\
\text { rice grown normally } \\
\text { under } 50 \mu \mathrm{M} \text { oxyfluorfen } \\
\text { while wild type bleached } \\
\text { and necrotized }\end{array}$ & Jung et al. (2004a) \\
\hline
\end{tabular}

The symbol + shows positive regulation and - shows negative regulation 
Fig. 3 Overview for biosynthesis, metabolism and application of ALA in medical and agricultural fields. The biosynthetic ways of ALA and its metabolic productions are shown (orange boxes). Moreover, beneath ALA are the potential roles of the metabolic productions could involve in physiological process of plants. In addition, the application aspects of ALA in medical and agricultural fields are shown (blue boxes). (Color figure online)

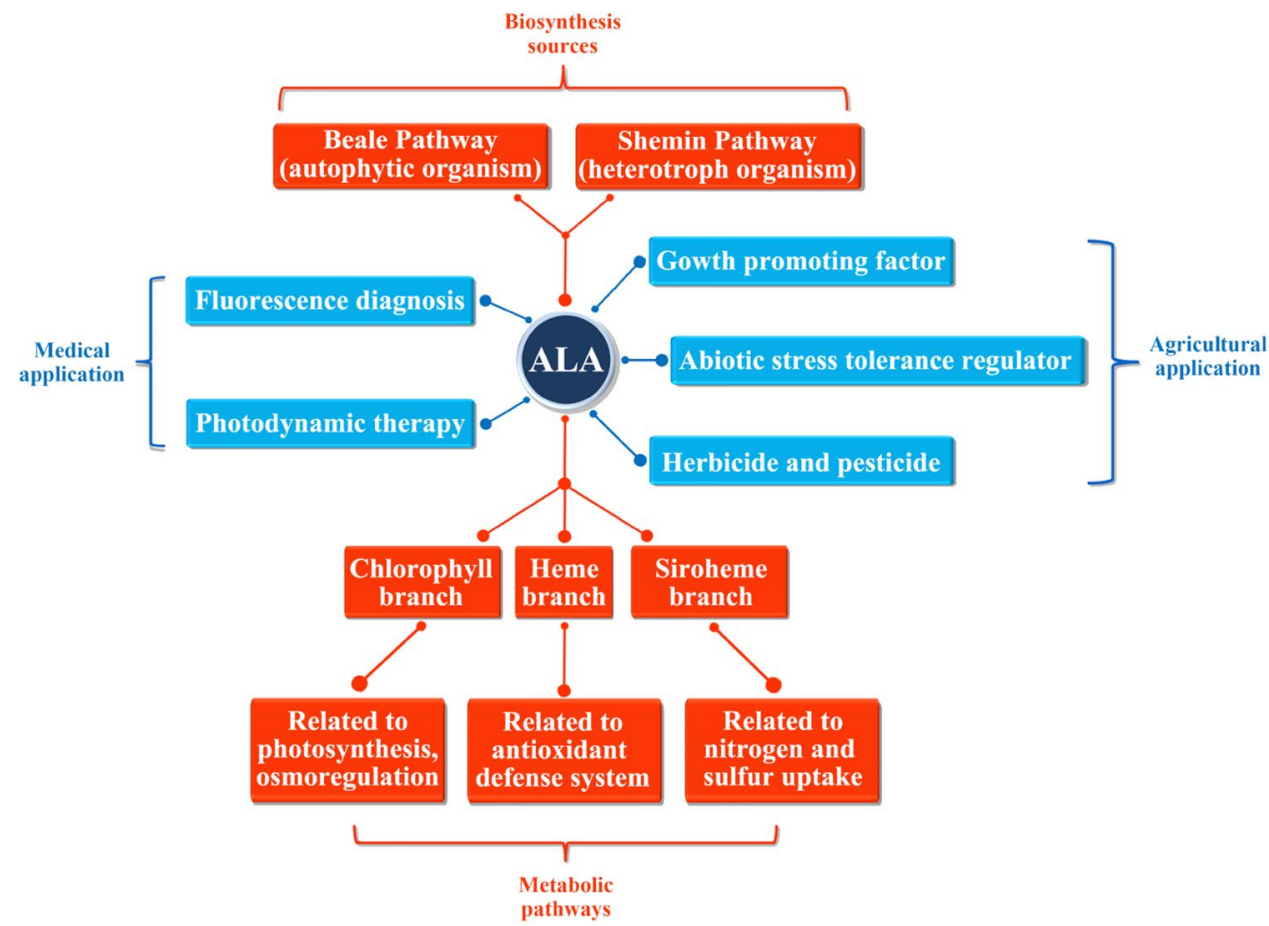

positive factors, like GUN4 protein (acts on $\mathrm{MCH}$ ) and FHY3/FAR1 protein (acts on ALAD); then negative factor, like FLU protein (acts on GluTR). However, the mechanism of feed-back regulation of heme towards ALA has not been elucidated. Thus, it is a viable area for research. Additionally, the control effect or balance regulation between branches of ALA downstream metabolism, like Fe-branch and Mg-branch, has not been adequately studied.

ALA does not only regulate plant growth and development (for example seed germination, vegetative growth and fruit coloring of crops) under non-stressful condition, but also helps improves plants resistance against abiotic stresses by regulating their photosynthesis, capacity of nutrients uptake, antioxidant defense system and osmoregulation directly or indirectly. The great majority of existing researches on regulative role of ALA in plants focused on the physiological effects rather than the molecular mechanism. Further studies are recommended to investigate the mechanism at molecular level and to interpret the ameliorative role of ALA to various plant physiological and growth process in depth. In addition, there is another perspective that studies of the regulative mechanism of ALA could associated with its biosynthesis and metabolism pathway, which has barely received some research attention (Fig. 3).

As a plant growth regulator, there is a little research about interaction between ALA and other plant hormone. Therefore, this is a promising research point.

Transgenic breeding using genetic engineering methods is a powerful way to reform plant genome and modified crops for specific purposes. Therefore, application of genetic manipulation toward ALA biosynthesis and metabolic pathways to regulate and control the production of endogenous ALA or other intermediate materials can be a feasible way to enhance plant growth under stressful or non-stressful environment. Nevertheless, there are few researches in this area, and fewer of these studies succeeded in strengthening plant resistance to abiotic stresses. Therefore, studies in genetic engineering of ALA role in enhancing the stress tolerance of plants and in promoting plant growth are promising and require research attention.

Acknowledgements We are grateful to Prof. Yantai Gan (Agriculture and Agri-Food Canada, Swift Current Research and Development Centre, Swift Current, SK, Canada) who critically read the manuscript and made valuable suggestions for its improvement. This work was supported by the National Natural Science Foundation of China (No. 31660584), China Agriculture Research System (CARS-23-C-07) and Natural Science Foundation of Gansu References Province, China (1610RJZA098). Besides, the authors declare that they have no competing interests.

Author contributions YW who wrote the main body of the manuscript, figures and tables. WL who critical read the manuscript and offered a proposal to the figures. MMD who critical read the manuscript. LH who critical read the manuscript. JY is the corresponding author, who proposed the theme of this manuscript.

Open Access This article is distributed under the terms of the Creative Commons Attribution 4.0 International License (http://creativeco mmons.org/licenses/by/4.0/), which permits unrestricted use, distribution, and reproduction in any medium, provided you give appropriate credit to the original author(s) and the source, provide a link to the Creative Commons license, and indicate if changes were made. 


\section{References}

Aarti D, Tanaka R, Ito H, Tanaka A (2007) High light inhibits chlorophyll biosynthesis at the level of 5-aminolevulinate synthesis during de-etiolation in cucumber (Cucumis sativus) cotyledons. Photochem Photobiol 83(1):171-176. https://doi. org/10.1562/2006-03-06-RA-835

Ahmad P, Kumar A, Ashraf M, Akram NA (2012) Salt-induced changes in photosynthetic activity and oxidative defense system of three cultivars of mustard (Brassica juncea L.). Afr J Biotechnol 11(11):2694. https://doi.org/10.5897/AJB11.3203

Akram NA, Ashraf M (2011) Pattern of accumulation of inorganic elements in sunflower (Helianthus annuus L.) plants subjected to salt stress and exogenous application of 5-aminolevulinic acid. Pak J Bot 43(1):521-530

Akram NA, Ashraf M (2013) Regulation in plant stress tolerance by a potential plant growth regulator, 5 -aminolevulinic acid. J Plant Growth Regul 32(3):663-679. https://doi.org/10.1007/ s00344-013-9325-9

Akram NA, Ashraf M, Al-Qurainy F (2011) Aminolevulinic acidinduced changes in yield and seed-oil characteristics of sunflower (Helianthus annuus L.) plants under salt stress. Pak J Bot 43:2845-2852

Akram NA, Ashraf M, Al-Qurainy F (2012) Aminolevulinic acidinduced changes in some key physiological attributes and activities of antioxidant enzymes in sunflower (Helianthus annuus L.) plants under saline regimes. Sci Hortic (Amsterdam) 142:143-148. https://doi.org/10.1016/j.scienta.2012.05.007

Ali B, Huang C, Qi Z, Ali S, Daud M, Geng X, Liu H, Zhou W (2013a) 5-Aminolevulinic acid ameliorates cadmium-induced morphological, biochemical, and ultrastructural changes in seedlings of oilseed rape. Environ Sci Pollut Res 20(10):72567267. https://doi.org/10.1007/s11356-013-1735-5

Ali B, Wang B, Ali S, Ghani M, Hayat M, Yang C, Xu L, Zhou W (2013b) 5-Aminolevulinic acid ameliorates the growth, photosynthetic gas exchange capacity, and ultrastructural changes under cadmium stress in Brassica napus L. J Plant Growth Regul 32(3):604-614. https://doi.org/10.1007/s00344-013-9328-6

Ali B, Xu X, Gill RA, Yang S, Ali S, Tahir M, Zhou W (2014a) Promotive role of 5-aminolevulinic acid on mineral nutrients and antioxidative defense system under lead toxicity in Brassica napus. Ind Crop Prod 52:617-626. https://doi.org/10.1016/j. indcrop.2013.11.033

Ali B, Qian P, Jin R, Ali S, Khan M, Aziz R, Tian T, Zhou W (2014b) Physiological and ultra-structural changes in Brassica napus seedlings induced by cadmium stress. Biol Plant 58(1):131138. https://doi.org/10.1007/s10535-013-0358-5

Ali B, Gill RA, Yang S, Gill MB, Farooq MA, Liu D, Daud MK, Ali S, Zhou W (2015) Regulation of cadmium-induced proteomic and metabolic changes by 5-aminolevulinic acid in leaves of Brassica napus L. PLoS ONE 10(4):e0123328. https://doi. org/10.1371/journal.pone. 0123328

Amooaghaie R, Tabatabaei F, Ahadi A-m (2015) Role of hematin and sodium nitroprusside in regulating Brassica nigra seed germination under nanosilver and silver nitrate stresses. Ecotoxicol Environ Saf 113:259-270. https://doi.org/10.1016/j. ecoenv.2014.12.017

An Y, Qi L, Wang L (2016) ALA pretreatment improves waterlogging tolerance of fig plants. PLoS ONE 11(1):e0147202. https ://doi.org/10.1371/journal.pone.0147202

Apitz J, Schmied J, Lehmann MJ, Hedtke B, Grimm B (2014) GluTR2 complements a hema1 mutant lacking glutamyl-tRNA reductase 1 , but is differently regulated at the post-translational level. Plant Cell Physiol 55(3):645-657. https://doi.org/10.1093/pcp/pcu016
Apitz J, Nishimura K, Schmied J, Wolf A, Hedtke B, van Wijk KJ, Grimm B (2016) Posttranslational control of ALA synthesis includes GluTR degradation by Clp protease and stabilization by GluTR-binding protein. Plant Physiol 170(4):2040-2051. https ://doi.org/10.1104/pp.15.01945

Ashraf M, Harris P (2013) Photosynthesis under stressful environments: an overview. Photosynthetica 51(2):163-190. https://doi. org/10.1007/s11099-013-0021-6

Averina N, Gritskevich E, Vershilovskaya I, Usatov A, Yaronskaya E (2010) Mechanisms of salt stress tolerance development in barley plants under the influence of 5-aminolevulinic acid. Russ J Plant Physiol 57(6):792-798. https://doi.org/10.1134/S1021 443710060075

Awad MA (2008) Promotive effects of a 5-aminolevulinic acid-based fertilizer on growth of tissue culture-derived date palm plants (Phoenix dactylifera L.) during acclimatization. Sci Hortic (Amsterdam) 118(1):48-52. https://doi.org/10.1016/j.scien ta.2008.05.034

Awad MA, Al-Qurashi AD (2011) Promotive effects of 5-aminolevulinic acid on growth of young 'Barhee'tissue culture-derived date palm (Phoenix dactylifera L.) trees in a newly established orchard. J Food Agric Environ 9(2):783-786

Ayala A, Muñoz MF, Argüelles S (2014) Lipid peroxidation: production, metabolism, and signaling mechanisms of malondialdehyde and 4-hydroxy-2-nonenal. Oxid Med Cell Longev. https://doi. org/10.1155/2014/360438

Balestrasse KB, Tomaro ML, Batlle A, Noriega GO (2010) The role of 5-aminolevulinic acid in the response to cold stress in soybean plants. Phytochemistry 71(17):2038-2045. https://doi. org/10.1016/j.phytochem.2010.07.012

Bali S, Rollauer S, Roversi P, Raux-Deery E, Lea SM, Warren MJ, Ferguson SJ (2014) Identification and characterization of the 'missing'terminal enzyme for siroheme biosynthesis in $\alpha$-proteobacteria. Mol Microbiol 92(1):153-163. https://doi. org/10.1111/mmi.12542

Beale SI (1970) The biosynthesis of $\delta$-aminolevulinic acid in Chlorella. Plant Physiol 45(4):504-506. https://doi.org/10.1104/ pp.45.4.504

Beale SI, Castelfranco PA (1974) The biosynthesis of $\delta$-aminolevulinic acid in higher plants I. Accumulation of $\delta$-aminolevulinic acid in greening plant tissues. Plant Physiol 53(2):291-296. https://doi. org/10.1104/pp.53.2.291

Beyzaei Z, Sherbakov RA, Averina NG (2014) Response of nitrate reductase to exogenous application of 5-aminolevulinic acid in barley plants. J Plant Growth Regul 33(4):745-750. https://doi. org/10.1007/s00344-014-9422-4

Bindu RC, Vivekanandan M (1998) Hormonal activities of 5-aminolevulinic acid in callus induction and micropropagation. Plant Growth Regul 26(1):15-18. https://doi.org/10.1023/a:10060 98005335

Boyer JS, Byrne P, Cassman KG, Cooper M, Delmer D, Greene T, Gruis F, Habben J, Hausmann N, Kenny N, Lafitte R, Paszkiewicz S, Porter D, Schlegel A, Schussler J, Setter T, Shanahan J, Sharp RE, Vyn TJ, Warner D, Gaffney J (2013) The U.S. drought of 2012 in perspective: a call to action. Glob Food Secur 2(3):139-143. https://doi.org/10.1016/j.gfs.2013.08.002

Bradshaw RE, Dixon SWC, Raitt DC, Pillar TM (1993) Isolation and nucleotide sequence of the 5-aminolevulinate synthase gene from Aspergillus nidulans. Curr Genet 23(5):501-507. https:// doi.org/10.1007/bf00312642

Chagné D, Kirk C, How N, Whitworth C, Fontic C, Reig G, Sawyer G, Rouse S, Poles L, Gardiner SE (2016) A functional genetic marker for apple red skin coloration across different environments. Tree Genet Genomes 12(4):1-9. https://doi. org/10.1007/s11295-016-1025-8 
Chan Z, Shi H (2015) Improved abiotic stress tolerance of bermudagrass by exogenous small molecules. Plant Signal Behav 10(3):e991577. https://doi.org/10.4161/15592324.2014.99157 7

Chekounova E, Voronetskaya V, Papenbrock J, Grimm B, Beck C (2001) Characterization of Chlamydomonas mutants defective in the H subunit of Mg-chelatase. Mol Genet Genom 266(3):363373. https://doi.org/10.1007/s004380100574

Chen M (2014) Chlorophyll modifications and their spectral extension in oxygenic photosynthesis. Annu Rev Biochem 83:317-340. https://doi.org/10.1146/annurev-biochem-072711-162943

Chen L, Guo Y, Bai G, Sun J, Li Y (2015) Effect of 5-aminolevulinic acid and genistein on accumulation of polyphenol and anthocyanin in'Qinyang' apples. J Anim Plant Sci 25:68-79

Chen G, Fan PS, Feng WM, Guan AQ, Lu YY, Wan YL (2017) Effects of 5-aminolevulinic acid on nitrogen metabolism and ion distribution of watermelon seedlings under salt stress. Russ J Plant Physiol 64(1):116-123. https://doi.org/10.1134/S102144371 7010046

Choi C, Hong B-S, Sung H-C, Lee H-S, Kim J-H (1999) Optimization of extracellular 5-aminolevulinic acid production from Escherichia coli transformed with ALA synthase gene of Bradyrhizobium japonicum. Biotechnol Lett 21(6):551-554. https://doi. org/10.1023/a:1005520007230

Chon S-U (2003) Herbicidal activity of $\delta$-aminolevulinic acid on several plants as affected by application methods. Korean J Crop Sci 48(1):50-55

Choudhury FK, Rivero RM, Blumwald E, Mittler R (2016) Reactive oxygen species, abiotic stress and stress combination. Plant J. https://doi.org/10.1111/tpj.13299

Cosgarea R, Susan M, Crisan M, Senila S (2013) Photodynamic therapy using topical 5-aminolaevulinic acid vs. surgery for basal cell carcinoma. J Eur Acad Dermatol 27(8):980-984. https://doi.org/ 10.1111/j.1468-3083.2012.04619.x

Czarnecki O, Grimm B (2012) Post-translational control of tetrapyrrole biosynthesis in plants, algae, and cyanobacteria. J Exp Bot 63(4):1675-1687. https://doi.org/10.1093/jxb/err437

Czarnecki O, Hedtke B, Melzer M, Rothbart M, Richter A, Schröter Y, Pfannschmidt T, Grimm B (2011) An Arabidopsis GluTR binding protein mediates spatial separation of 5-aminolevulinic acid synthesis in chloroplasts. Plant Cell 23(12):4476-4491. https:// doi.org/10.1105/tpc.111.086421

Dailey HA, Meissner PN (2013) Erythroid heme biosynthesis and its disorders. Csh Perspect Med 3(4):a011676. https://doi. org/10.1101/cshperspect.a011676

Dayan FE, Duke SO (2014) Natural compounds as next-generation herbicides. Plant Physiol 166(3):1090-1105. https://doi. org/10.1104/pp.114.239061

de Menezes Daloso D, Antunes WC, Santana TA, Pinheiro DP, Ribas RF, Sachetto-Martins G, Loureiro ME (2014) Arabidopsis gun4 mutant have greater light energy transfer efficiency in photosystem II despite low chlorophyll content. Theor Exp Plant Phys 26(3-4):177-187. https://doi.org/10.1007/s40626-014-0025-z

Dietz K-J, Turkan I, Krieger-Liszkay A (2016) Redox-and reactive oxygen species-dependent signaling into and out of the photosynthesizing chloroplast. Plant Physiol 171(3):1541-1550. https ://doi.org/10.1104/pp.16.00375

Espinas NA, Kobayashi K, Takahashi S, Mochizuki N, Masuda T (2012) Evaluation of unbound free heme in plant cells by differential acetone extraction. Plant Cell Physiol 53(7):1344-1354. https://doi.org/10.1093/pcp/pcs067

Feng X, Cheng S, Jun Z, Zhang W, Yan W (2011) Effects of 5-aminolevulinic acid on chlorophyll, photosynthesis, soluble sugar and flavonoids of Ginkgo biloba. Not Bot Horti Agrobot 39(1):41. https://doi.org/10.15835/nbha3915880
Feng S, Li MF, Wu F, Li WL, Li SP (2015) 5-Aminolevulinic acid affects fruit coloration, growth, and nutrition quality of Litchi chinensis Sonn. cv. Feizixiao in Hainan, tropical China. Sci Hortic (Amsterdam) 193:188-194. https://doi.org/10.1016/j.scien ta.2015.07.010

Feng X, An Y, Zheng J, Sun M, Wang L (2016) Proteomics and SSH analyses of ALA-promoted fruit coloration and evidence for the involvement of a MADS-box gene, MdMADS1. Front Plant Sci. https://doi.org/10.3389/fpls.2016.01615

Fu J, Sun Y, Chu X, Xu Y, Hu T (2014) Exogenous 5-aminolevulenic acid promotes seed germination in Elymus nutans against oxidative damage induced by cold stress. PLoS ONE 9(9):e107152. https://doi.org/10.1371/journal.pone.0107152

Garai S, Joshi NC, Tripathy BC (2016) Phylogenetic analysis and photoregulation of siroheme biosynthesis genes: uroporphyrinogen III methyltransferase and sirohydrochlorin ferrochelatase of Arabidopsis thaliana. Physiol Mol Biol Plants 22(3):351-359. https://doi.org/10.1007/s12298-016-0363-1

Gechev TS, Hille J (2012) Molecular basis of plant stress. Cell Mol Life Sci. https://doi.org/10.1007/s00018-012-1086-2

Gill RA, Ali B, Islam F, Farooq MA, Gill MB, Mwamba TM, Zhou W (2015) Physiological and molecular analyses of black and yellow seeded Brassica napus regulated by 5 -aminolivulinic acid under chromium stress. Plant Physiol Biochem 94:130-143. https://doi. org/10.1016/j.plaphy.2015.06.001

Guaragna A, Roviello GN, D'Errico S, Paolella C, Palumbo G, D'Alonzo D (2015) Solid phase synthesis of a novel folate-conjugated 5-aminolevulinic acid methyl ester based photosensitizer for selective photodynamic therapy. Tetrahedron Lett 56(6):775778. https://doi.org/10.1016/j.tetlet.2014.12.028

Gupta P, Jain M, Sarangthem J, Gadre R (2013) Inhibition of 5-aminolevulinic acid dehydratase by mercury in excised greening maize leaf segments. Plant Physiol Biochem 62:63-69. https:// doi.org/10.1016/j.plaphy.2012.10.008

Hara M, Takahashi I, Yamori M, Tanaka T, Funada S, Watanabe K (2011) Effects of 5-aminolevulinic acid on growth and amylase activity in the radish taproot. Plant Growth Regul 64(3):287-291. https://doi.org/10.1007/s10725-010-9542-1

Harel E, Klein S (1972) Light dependent formation of $\delta$-aminolevulinic acid in etiolated leaves of higher plants. Biochem Biophy Res Commun 49(2):364-370. https://doi.org/10.1016/0006291X(72)90419-6

Hedtke B, Alawady A, Chen S, Börnke F, Grimm B (2007) HEMA RNAi silencing reveals a control mechanism of ALA biosynthesis on Mg chelatase and Fe chelatase. Plant Mol Biol 64(6):733742. https://doi.org/10.1007/s11103-007-9194-3

Herbert ER, Boon P, Burgin AJ, Neubauer SC, Franklin RB, Ardón M, Hopfensperger KN, Lamers LPM, Gell P (2015) A global perspective on wetland salinization: ecological consequences of a growing threat to freshwater wetlands. Ecosphere 6(10):1-43. https://doi.org/10.1890/ES14-00534.1

Hillemanns P, Wimberger P, Reif J, Stepp H, Klapdor R (2017) Photodynamic diagnosis with 5-aminolevulinic acid for intraoperative detection of peritoneal metastases of ovarian cancer: a feasibility and dose finding study. Laser Surg Med 49(2):169-176. https:// doi.org/10.1002/lsm.22613

Hu L, Yu J, Liao W, Zhang G, Xie J, Lv J, Xiao X, Yang B, Zhou R, $\mathrm{Bu} \mathrm{R}$ (2015) Moderate ammonium: nitrate alleviates low light intensity stress in mini Chinese cabbage seedling by regulating root architecture and photosynthesis. Sci Hortic (Amsterdam) 186:143-153. https://doi.org/10.1016/j.scienta.2015.02.020

Huang S, Van Aken O, Schwarzländer M, Belt K, Millar AH (2016) The roles of mitochondrial reactive oxygen species in cellular signaling and stress response in plants. Plant Physiol 171(3):1551-1559. https://doi.org/10.1104/pp.16.00166 
Hudson D, Guevara D, Yaish MW, Hannam C, Long N, Clarke JD, Bi Y-M, Rothstein SJ (2011) GNC and CGA1 modulate chlorophyll biosynthesis and glutamate synthase (GLU1/Fd-GOGAT) expression in Arabidopsis. PLoS ONE 6(11):e26765. https://doi. org/10.1371/journal.pone.0026765

Jeong ST, Goto-Yamamoto N, Kobayashi S, Esaka M (2004) Effects of plant hormones and shading on the accumulation of anthocyanins and the expression of anthocyanin biosynthetic genes in grape berry skins. Plant Sci 167(2):247-252. https://doi.org/10.1016/j. plantsci.2004.03.021

Jung S, Back K (2005) Herbicidal and antioxidant responses of transgenic rice overexpressing Myxococcus xanthus protoporphyrinogen oxidase. Plant Physiol Biochem 43(5):423-430. https://doi. org/10.1016/j.plaphy.2005.03.008

Jung S, Lee Y, Yang K, Lee SB, Jang SM, Ha SB, Back K (2004a) Dual targeting of Myxococcus xanthus protoporphyrinogen oxidase into chloroplasts and mitochondria and high level oxyfluorfen resistance. Plant Cell Environ 27(11):1436-1446. https://doi.org /10.1111/j.1365-3040.2004.01247.x

Jung S, Yang K, Lee D-E, Back K (2004b) Expression of Bradyrhizobium japonicum 5-aminolevulinic acid synthase induces severe photodynamic damage in transgenic rice. Plant Sci 167(4):789795. https://doi.org/10.1016/j.plantsci.2004.05.038

Jung S, Back K, Yang K, Kuk Y, Chon S-U (2008a) Defence response produced during photodynamic damage in transgenic rice overexpressing 5-aminolevulinic acid synthase. Photosynthetica 46(1):3-9. https://doi.org/10.1007/s11099-008-0002-3

Jung S, Lee H-J, Lee Y, Kang K, Kim YS, Grimm B, Back K (2008b) Toxic tetrapyrrole accumulation in protoporphyrinogen IX oxidase-overexpressing transgenic rice plants. Plant Mol Biol 67(5):535-546. https://doi.org/10.1007/s11103-008-9338-0

Kauss D, Bischof S, Steiner S, Apel K, Meskauskiene R (2012) FLU, a negative feedback regulator of tetrapyrrole biosynthesis, is physically linked to the final steps of the $\mathrm{Mg}^{++}$-branch of this pathway. FEBS Lett 586(3):211-216. https://doi.org/10.1016/j. febslet.2011.12.029

Kelley CP, Mohtadi S, Cane MA, Seager R, Kushnir Y (2015) Climate change in the Fertile Crescent and implications of the recent Syrian drought. P Natl Acad Sci 112(11):3241-3246. https://doi. org/10.1073/pnas.1421533112

Kim J-G, Back K, Lee HY, Lee H-J, Phung T-H, Grimm B, Jung S (2014) Increased expression of Fe-chelatase leads to increased metabolic flux into heme and confers protection against photodynamically induced oxidative stress. Plant Mol Biol 86(3):271287. https://doi.org/10.1007/s11103-014-0228-3

Kořený L, Oborník M, Lukeš J (2013) Make it, take it, or leave it: heme metabolism of parasites. PLoS Pathog 9(1):e1003088. https://doi. org/10.1371/journal.ppat.1003088

Korkmaz A, Korkmaz Y (2009) Promotion by 5-aminolevulenic acid of pepper seed germination and seedling emergence under lowtemperature stress. Sci Hortic (Amsterdam) 119(2):98-102. https ://doi.org/10.1016/j.scienta.2008.07.016

Kosar F, Akram N, Ashraf M (2015) Exogenously-applied 5-aminolevulinic acid modulates some key physiological characteristics and antioxidative defense system in spring wheat (Triticum aestivum L.) seedlings under water stress. S Afr J Bot 96:71-77. https ://doi.org/10.1016/j.sajb.2014.10.015

Kuk Y-I, Lim G-S, Chon S-U, Hwang T-E, Guh J-O (2003) Effects of 5 -aminolevulinic acid on growth and inhibition of various plant species. Korean J Crop Sci 48(2):127-133

Kumar AM, Söll D (2000) Antisense HEMA1 RNA expression inhibits heme and chlorophyll biosynthesis in Arabidopsis. Plant Physiol 122(1):49-56. https://doi.org/10.1104/pp.122.1.49

Kunugi M, Takabayashi A, Tanaka A (2013) Evolutionary changes in chlorophyllide a oxygenase (CAO) structure contribute to the acquisition of a new light-harvesting complex in Micromonas. J Biol Chem 288(27):19330-19341. https://doi.org/10.1074/jbc. M113.462663

Kwon SW, Sohn EJ, Kim DW, Jeong HJ, Kim MJ, Ahn EH, Kim YN, Dutta S, Kim D-S, Park J (2011) Anti-inflammatory effect of transduced PEP-1-heme oxygenase-1 in Raw 264.7 cells and a mouse edema model. Biochem Biophy Res Commun 411(2):354-359. https://doi.org/10.1016/j.bbrc.2011.06.147

Lee KP, Kim C, Lee DW, Apel K (2003) TIGRINA d, required for regulating the biosynthesis of tetrapyrroles in barley, is an ortholog of the FLU gene of Arabidopsis thaliana. FEBS Lett 553(1-2):119124. https://doi.org/10.1016/S0014-5793(03)00983-9

Lermontova I, Grimm B (2000) Overexpression of plastidic protoporphyrinogen IX oxidase leads to resistance to the diphenyl-ether herbicide acifluorfen. Plant Physiol 122(1):75-84. https://doi. org/10.1104/pp.122.1.75

Li Y, Liu Y, Zhang J (2010) Advances in the research on the AsA-GSH cycle in horticultural crops. Front Agric China 4(1):84-90. https ://doi.org/10.1007/s11703-009-0089-8

Li D-M, Zhang J, Sun W-J, Li Q, Dai A-H, Bai J-G (2011) 5-Aminolevulinic acid pretreatment mitigates drought stress of cucumber leaves through altering antioxidant enzyme activity. Sci Hortic (Amsterdam) 130(4):820-828. https://doi.org/10.1016/j.scien ta.2011.09.010

Li Y, Li H, Wang F, Li J, Zhang Y, Wang L, Gao J (2016) Comparative transcriptome analysis reveals effects of exogenous hematin on anthocyanin biosynthesis during strawberry fruit ripening. Int $\mathbf{J}$ Genom. https://doi.org/10.1155/2016/6762731

Liu D, Pei Z, Naeem M, Ming D, Liu H, Khan F, Zhou W (2011) 5-Aminolevulinic acid activates antioxidative defence system and seedling Growth in Brassica napus L. under water-deficit stress. J Agron Crop Sci 197(4):284-295. https://doi.org/10.1111/j.1439037X.2011.00465.x

Liu L, Nguyen NT, Ueda A, Saneoka H (2014) Effects of 5-aminolevulinic acid on Swiss chard (Beta vulgaris L. subsp. cicla) seedling growth under saline conditions. Plant Growth Regul 74(3):219-228. https://doi.org/10.1007/s10725-014-9913-0

Liu D, Kong DD, Fu XK, Ali B, Xu L, Zhou WJ (2016) Influence of exogenous 5-aminolevulinic acid on chlorophyll synthesis and related gene expression in oilseed rape de-etiolated cotyledons under water-deficit stress. Photosynthetica 54(3):468-474. https ://doi.org/10.1007/s11099-016-0197-7

Liu T, Hu X, Zhang J, Zhang J, Du Q, Li J (2018) $\mathrm{H}_{2} \mathrm{O}_{2}$ mediates ALA-induced glutathione and ascorbate accumulation in the perception and resistance to oxidative stress in Solanum lycopersicumat low temperatures. BMC Plant Biol 18(1):34. https:// doi.org/10.1186/s12870-018-1254-0

Liu D, Wu L, Naeem MS, Liu H, Deng X, Xu L, Zhang F, Zhou W (2013) 5-Aminolevulinic acid enhances photosynthetic gas exchange, chlorophyll fluorescence and antioxidant system in oilseed rape under drought stress. Acta Physiologiae Plantarum 35(9):2747-2759. https://doi.org/10.1007/s11738-013-1307-9

Lobell DB, Hammer GL, Chenu K, Zheng B, McLean G, Chapman SC (2015) The shifting influence of drought and heat stress for crops in northeast Australia. Global Change Biol 21(11):4115-4127. https://doi.org/10.1111/gcb.13022

Maruyama-Nakashita A, Hirai MY, Funada S, Fueki S (2010) Exogenous application of 5-aminolevulinic acid increases the transcript levels of sulfur transport and assimilatory genes, sulfate uptake, and cysteine and glutathione contents in Arabidopsis thaliana. Soil Sci Plant Nutr 56(2):281-288. https://doi.org/10. 1111/j.1747-0765.2010.00458.x

McClung CR, Somerville JE, Guerinot ML, Chelm BK (1987) Structure of the Bradyrhizobium japonicum gene hemA encoding 
5-aminolevulinic acid synthase. Gene 54(1):133-139. https:// doi.org/10.1016/0378-1119(87)90355-6

McCormac AC, Terry MJ (2002) Light-signalling pathways leading to the co-ordinated expression of HEMAl and Lhcb during chloroplast development in Arabidopsis thaliana. Plant J 32(4):549-559. https://doi.org/10.1046/j.1365313X.2002.01443.X

Memon SA, Hou X, Wang L, Li Y (2009) Promotive effect of 5-aminolevulinic acid on chlorophyll, antioxidative enzymes and photosynthesis of Pakchoi (Brassica campestris ssp. chinensis var. communis Tsen et Lee). Acta Physiol Plant 31(1):51. https ://doi.org/10.1007/s11738-008-0198-7

Mickelbart MV, Hasegawa PM, Bailey-Serres J (2015) Genetic mechanisms of abiotic stress tolerance that translate to crop yield stability. Nat Rev Genet 16(4):237-251. https://doi. org/10.1038/nrg3901

Morton C, Szeimies RM, Sidoroff A, Braathen L (2013) European guidelines for topical photodynamic therapy part 1: treatment delivery and current indications-actinic keratoses, Bowen's disease, basal cell carcinoma. J Eur Acad Dermatol 27(5):536544. https://doi.org/10.1111/jdv.12031

Naeem M, Jin Z, Wan G, Liu D, Liu H, Yoneyama K, Zhou W (2010) 5-Aminolevulinic acid improves photosynthetic gas exchange capacity and ion uptake under salinity stress in oilseed rape (Brassica napus L.). Plant Soil 332(1-2):405-415. https://doi. org/10.1007/s11104-010-0306-5

Naeem M, Rasheed M, Liu D, Jin Z, Ming D, Yoneyama K, Takeuchi Y, Zhou W (2011) 5-Aminolevulinic acid ameliorates salinityinduced metabolic, water-related and biochemical changes in Brassica napus L. Acta Physiol Plant 33(2):517-528. https:// doi.org/10.1007/s11738-010-0575-x

Naeem MS, Warusawitharana H, Liu H, Liu D, Ahmad R, Waraich EA, Xu L, Zhou W (2012) 5-Aminolevulinic acid alleviates the salinity-induced changes in Brassica napus as revealed by the ultrastructural study of chloroplast. Plant Physiol Bioch 57:84-92. https://doi.org/10.1016/j.plaphy.2012.05.018

Nagahatenna DS, Langridge P, Whitford R (2015) Tetrapyrrolebased drought stress signalling. Plant Biotechnol J 13(4):447459. https://doi.org/10.1111/pbi.12356

Neidle E, Kaplan S (1993) Expression of the Rhodobacter sphaeroides hemA and hemT genes, encoding two 5-aminolevulinic acid synthase isozymes. J Bacteriol 175(8):2292-2303. https://doi.org/10.1128/jb.175.8.2292-2303.1993

Nguyen H, Kim H-S, Jung S (2016) Altered tetrapyrrole metabolism and transcriptome during growth-promoting actions in rice plants treated with 5-aminolevulinic acid. Plant Growth Regul 78(1):133-144. https://doi.org/10.1007/s10725-015-0080-8

Nickelsen J, Rengstl B, Stengel A, Schottkowski M, Soll J, Ankele E (2011) Biogenesis of the cyanobacterial thylakoid membrane system - an update. FEMS Microbiol Lett 315(1):1-5. https:// doi.org/10.1111/j.1574-6968.2010.02096.x

Nishihara E, Kondo K, Parvez MM, Takahashi K, Watanabe K, Tanaka K (2003) Role of 5-aminolevulinic acid (ALA) on active oxygen-scavenging system in NaCl-treated spinach (Spinacia oleracea). J Plant Physiol 160(9):1085-1091. https://doi. org/10.1078/0176-1617-00991

Nunkaew T, Kantachote D, Kanzaki H, Nitoda T, Ritchie RJ (2014) Effects of 5-aminolevulinic acid (ALA)-containing supernatants from selected Rhodopseudomonas palustris strains on rice growth under $\mathrm{NaCl}$ stress, with mediating effects on chlorophyll, photosynthetic electron transport and antioxidative enzymes. Electron J Biotechnol 17(1):4-4. https://doi. org/10.1016/j.ejbt.2013.12.004

Oracz K, Voegele A, Tarkowská D, Jacquemoud D, Turečková V, Urbanová T, Strnad M, Sliwinska E, Leubner-Metzger G (2011) Myrigalone A inhibits Lepidium sativum seed germination by interference with gibberellin metabolism and apoplastic superoxide production required for embryo extension growth and endosperm rupture. Plant Cell Physiol 53(1):81-95. https://doi.org/10.1093/pcp/pcr124

Papenbrock J, Grimm B (2001) Regulatory network of tetrapyrrole biosynthesis-studies of intracellular signalling involved in metabolic and developmental control of plastids. Planta 213(5):667-681. https://doi.org/10.1007/s004250100593

Paramonova N, Shevyakova N, Kuznetsov VV (2004) Ultrastructure of chloroplasts and their storage inclusions in the primary leaves of Mesembryanthemum crystallinum affected by putrescine and $\mathrm{NaCl}$. Russ J Plant Physiol 51(1):86-96. https://doi. org/10.1023/B:RUPP.0000011307.95130.8f

Pereira LB, Tabaldi LA, Gonçalves JF, Jucoski GO, Pauletto MM, Weis SN, Nicoloso FT, Borher D, Rocha JBT, Schetinger MRC (2006) Effect of aluminum on $\delta$-aminolevulinic acid dehydratase (ALA-D) and the development of cucumber (Cucumis sativus). Environ Exp Bot 57(1):106-115. https:// doi.org/10.1016/j.envexpbot.2005.05.004

Phung T-H, Jung S (2014) Perturbed porphyrin biosynthesis contributes to differential herbicidal symptoms in photodynamically stressed rice (Oryza sativa) treated with 5-aminolevulinic acid and oxyfluorfen. Pestic Biochem Phys 116:103-110. https:// doi.org/10.1016/j.pestbp.2014.10.002

Piao S, Ciais P, Friedlingstein P, Peylin P, Reichstein M, Luyssaert S, Margolis H, Fang J, Barr A, Chen A (2008) Net carbon dioxide losses of northern ecosystems in response to autumn warming. Nature 451(7174):49-52. https://doi.org/10.1038/nature06444

Richter AS, Grimm B (2013) Thiol-based redox control of enzymes involved in the tetrapyrrole biosynthesis pathway in plants. Front Plant Sci 4:371. https://doi.org/10.3389/fpls.2013.00371

Richter A, Peter E, Pörs Y, Lorenzen S, Grimm B, Czarnecki O (2010) Rapid dark repression of 5-aminolevulinic acid synthesis in green barley leaves. Plant Cell Physiol 51(5):670-681. https://doi.org/10.1093/pcp/pcq047

Rodríguez-Serrano M, Romero-Puertas MC, Sanz-Fernández M, Hu J, Sandalio LM (2016) Peroxisomes extend peroxules in a fast response to stress via a reactive oxygen species-mediated induction of the peroxin PEX11a. Plant Physiol 171(3):16651674. https://doi.org/10.1104/pp.16.00648

Sasaki K, Watanabe M, Tanaka T (2002) Biosynthesis, biotechnological production and applications of 5-aminolevulinic acid. Appl Microbiol Biot 58(1):23-29. https://doi.org/10.1007/ s00253-001-0858-7

Senge MO, Ryan AA, Letchford KA, MacGowan SA, Mielke T (2014) Chlorophylls, symmetry, chirality, and photosynthesis. Symmetry 6(3):781-843. https://doi.org/10.3390/sym6030781

Shemin D, Russell CS (1953) $\delta$-Aminolevulinic acid, its role in the biosynthesis of porphyrins and purines. J Am Chem Soc 75(19):4873-4874. https://doi.org/10.1021/ja01115a546

Sheteiwy M, Shen H, Xu J, Guan Y, Song W, Hu J (2017) Seed polyamines metabolism induced by seed priming with spermidine and 5-aminolevulinic acid for chilling tolerance improvement in rice (Oryza sativa L.) seedlings. Environ Exp Bot 137:5872. https://doi.org/10.1016/j.envexpbot.2017.02.007

Singh A (2015) Soil salinization and waterlogging: A threat to environment and agricultural sustainability. Ecol Indic 57:128-130. https://doi.org/10.1016/j.ecolind.2015.04.027

Sobotka R (2014) Making proteins green; biosynthesis of chlorophyll-binding proteins in cyanobacteria. Photosynth Res 119(1-2):223-232. https://doi.org/10.1007/s11120-013-9797-2

Storbeck S, Saha S, Krausze J, Klink BU, Heinz DW, Layer G (2011) Crystal structure of the heme d1 biosynthesis enzyme NirE in complex with its substrate reveals new insights into the catalytic mechanism of S-adenosyl-L-methioninedependent uroporphyrinogen III methyltransferases. J Biol 
Chem 286(30):26754-26767. https://doi.org/10.1074/jbc. M111.239855

Su Y, Luo W, Lin W, Ma L, Kabir MH (2015) Model of cation transportation mediated by high-affinity potassium transporters (HKTs) in higher plants. Biol Proced Online 17(1):1. https:// doi.org/10.1186/s12575-014-0013-3

Sun Y-P, Zhang Z-P, Wang L-J (2009) Promotion of 5-aminolevulinic acid treatment on leaf photosynthesis is related with increase of antioxidant enzyme activity in watermelon seedlings grown under shade condition. Photosynthetica 47(3):347. https://doi. org/10.1007/s11099-009-0055-y

Sun YP, Liu J, Cao RX, Huang YJ, Hall AM, Guo CB, Wang LJ (2016) Effects of 5-aminolevulinic acid treatment on photosynthesis of strawberry. Photosynthetica 55(2):1-9. https://doi.org/10.1007/ s11099-016-0667-y

Suzuki T, Masuda T, Singh DP, Tan F-C, Tsuchiya T, Shimada H, Ohta H, Smith AG, Takamiya K-i (2002) Two types of ferrochelatase in photosynthetic and nonphotosynthetic tissues of cucumber. Their difference in phylogeny, gene expression, and localization. J Biol Chem 277(7):4731-4737. https://doi.org/10.1074/ jbc.M105613200

Tabuchi K, Mizuta H, Yasui H (2009) Promotion of callus propagation by 5 -aminolevulinic acid in a Laminaria japonica sporophyte. Aquac Res 41(1):1-10. https://doi.org/10.111 1/j.1365-2109.2009.02294.x

Taghizadeh M, Kafi M, Ftahi Moghadam M (2015) Breeding by In vitro culture to improve tolerance and accumulation of lead in Cynodon dactylon L. J Agric Sci Technol (Iran) 17:1851-1860

Tanaka R, Tanaka A (2007) Tetrapyrrole biosynthesis in higher plants. Annu Rev Plant Biol 58:321-346. https://doi.org/10.1146/annur ev.arplant.57.032905.105448

Tang W, Wang W, Chen D, Ji Q, Jing Y, Wang H, Lin R (2012) Transposase-derived proteins FHY3/FAR1 interact with phytochromeinteracting factor1 to regulate chlorophyll biosynthesis by modulating HEMB1 during deetiolation in Arabidopsis. Plant Cell 24(5):1984-2000. https://doi.org/10.1105/tpc.112.097022

Tripathy BC, Sherameti I, Oelmüller R (2010) Siroheme: an essential component for life on earth. Plant Signal Behav 5(1):14-20. https ://doi.org/10.4161/psb.5.1.10173

Vimolmangkang S, Zheng D, Han Y, Khan MA, Soria-Guerra RE, Korban SS (2014) Transcriptome analysis of the exocarp of apple fruit identifies light-induced genes involved in red color pigmentation. Gene 534(1):78-87. https://doi.org/10.1016/j. gene.2013.10.007

Wang P, Grimm B (2015) Organization of chlorophyll biosynthesis and insertion of chlorophyll into the chlorophyll-binding proteins in chloroplasts. Photosynth Res 126(2-3):189-202. https://doi. org/10.1007/s11120-015-0154-5

Wang M, Liao W (2016) Carbon monoxide as a signaling molecule in plants. Front Plant Sci. https://doi.org/10.3389/fpls.2016.00572

Wang Y, Li L, Cui W, Xu S, Shen W, Wang R (2012) Hydrogen sulfide enhances alfalfa (Medicago sativa) tolerance against salinity during seed germination by nitric oxide pathway. Plant Soil 351(12):107-119. https://doi.org/10.1007/s11104-011-0936-2

Wang Y, Li J, Gu W, Zhang Q, Tian L, Guo S, Wei S (2018) Exogenous application of 5-aminolevulinic acid improves low-temperature stress tolerance of maize seedlings. Crop Pasture Sci 69(6):587593. https://doi.org/10.1071/CP17401

Watanabe K, Nishihara E, Watanabe S, Tanaka T, Takahashi K, Takeuchi Y (2006) Enhancement of growth and fruit maturity in 2-year-old grapevines cv. Delaware by 5 -aminolevulinic acid. Plant Growth Regul 49(1):35-42. https://doi.org/10.1007/s1072 5-006-0024-4

Wegiel B, Nemeth Z, Correa-Costa M, Bulmer AC, Otterbein LE (2014) Heme oxygenase-1: a metabolic nike. Antioxid Redox Signal 20(11):1709-1722. https://doi.org/10.1089/ars.2013.5667
Wei ZY, Zhang ZP, Lee MR, Sun YP, Wang LJ (2012) Effect of 5-aminolevulinic acid on leaf senescence and nitrogen metabolism of pakchoi under different nitrate levels. J Plant Nutr 35(1):49-63. https://doi.org/10.1080/01904167.2012.631666

Wu Y, Jin X, Liao W, Hu L, Dawuda MM, Zhao X, Tang Z, Gong $\mathrm{T}, \mathrm{Yu} J$ (2018) 5-Aminolevulinic acid (ALA) alleviated salinity stress in cucumber seedlings by enhancing chlorophyll synthesis pathway. Front Plant Sci 9:635. https://doi.org/10.3389/ fpls.2018.00635

Xie L, Wang Z, Cheng X, Gao J, Zhang Z, Wang L (2013) 5-Aminolevulinic acid promotes anthocyanin accumulation in Fuji apples. Plant Growth Regul 69(3):295-303. https://doi.org/10.1007/ s10725-012-9772-5

Xie Y, Mao Y, Xu S, Zhou H, Duan X, Cui W, Zhang J, Xu G (2015) Heme-heme oxygenase 1 system is involved in ammonium tolerance by regulating antioxidant defence in Oryza sativa. Plant Cell Environ 38(1):129-143. https://doi.org/10.1111/pce.12380

Xiong J-L, Wang H-C, Tan X-Y, Zhang C-L, Naeem MS (2018) 5-aminolevulinic acid improves salt tolerance mediated by regulation of tetrapyrrole and proline metabolism in Brassica napus L. seedlings under $\mathrm{NaCl}$ stress. Plant Physiol Biochem 124:88-99. https://doi.org/10.1016/j.plaphy.2018.01.001

Xu L, Zhang W, Ali B, Islam F, Zhu J, Zhou W (2015) Synergism of herbicide toxicity by 5 -aminolevulinic acid is related to physiological and ultra-structural disorders in crickweed (Malachium aquaticum L.). Pestic Biochem Phys 125:53-61. https://doi. org/10.1016/j.pestbp.2015.06.002

Yamamoto S, Hayashi S, Furusaki S, Shioya S (2015) 5-Aminolevulinic acid promotes callus growth and paclitaxel production in light-grown Taxus cuspidata suspension cultures. Eng Life Sci 15(1):116-121. https://doi.org/10.1002/elsc.201300171

Yang Z, Chang Z, Sun L, Yu J, Huang B (2014) Physiological and metabolic effects of 5-aminolevulinic acid for mitigating salinity stress in creeping bentgrass. PLoS ONE 9(12):e116283. https:// doi.org/10.1371/journal.pone.0116283

Ye JB, Chen QW, Tao TT, Wang G, Xu F (2016) Promotive effects of 5-Aminolevulinic acid on growth, photosynthetic gas exchange, chlorophyll, and antioxidative enzymes under salinity stress in Prunnus persica (L.) Batseh Seedling. Emir J Food Agric 28(11):1. https://doi.org/10.9755/ejfa.2016-06-647

Ye J, Yang X, Chen Q, Xu F, Wang G (2017) Promotive effects of 5-aminolevulinic acid on fruit quality and coloration of Prunus persica (L.) Batsch. Sci Hortic 217:266-275. https://doi. org/10.1016/j.scienta.2017.02.009

Yonezawa T, Sunohara Y, Matsumoto H (2015) Involvement of heme synthesis in the growth stimulation of maize seedlings by 5 -aminolevulinic acid. Weed Biol Manag 15(1):53-60. https://doi. org/10.1111/wbm.12064

Youssef T, Awad MA (2008) Mechanisms of enhancing photosynthetic gas exchange in date palm seedlings (Phoenix dactylifera $\mathrm{L}$.) under salinity stress by a 5-aminolevulinic acid-based fertilizer. J Plant Growth Regul 27(1):1. https://doi.org/10.1007/s0034 4-007-9025-4

Yukimune Y, Hara Y, Nomura E, Seto H, Yoshida S (2000) The configuration of methyl jasmonate affects paclitaxel and baccatin III production in Taxus cells. Phytochemistry 54(1):13-17. https:// doi.org/10.1016/S0031-9422(00)00006-6

Yurina N, Osipenkova O, Odintsova M (2012) Higher plant tetrapyrrols: their biosynthesis and its regulation, tetrapyrrol role in transmission of retrograde signals. Russ J Plant Physiol 59(1):113. https://doi.org/10.1134/S1021443712010177

Zhang Z, Li H, Zhou W, Takeuchi Y, Yoneyama K (2006) Effect of 5-aminolevulinic acid on development and salt tolerance of potato (Solanum tuberosum L.) microtubers in vitro. Plant Growth Regul 49(1):27-34. https://doi.org/10.1007/s1072 5-006-0011-9 
Zhang Z-P, Yao Q-H, Wang L-J (2010) Expression of yeast Heml gene controlled by Arabidopsis HemA1 promoter improves salt tolerance in Arabidopsis plants. BMB Rep 43(5):330-336. https ://doi.org/10.5483/BMBRep.2010.43.5.330

Zhang J, Li D-M, Gao Y, Yu B, Xia C-X, Bai J-G (2012) Pretreatment with 5-aminolevulinic acid mitigates heat stress of cucumber leaves. Biol Plant 56(4):780-784. https://doi.org/10.1007/s1053 5-012-0136-9

Zhang C-P, Li Y-C, Yuan F-G, Hu S-J, Liu H-Y, He P (2013) Role of 5 -aminolevulinic acid in the salinity stress response of the seeds and seedlings of the medicinal plant Cassia obtusifolia $\mathrm{L}$. Bot Stud 54(1):18. https://doi.org/10.1186/1999-3110-54-18

Zhang J, Kang Z, Chen J, Du G (2015a) Optimization of the heme biosynthesis pathway for the production of 5-aminolevulinic acid in Escherichia coli. Sci Rep (UK). https://doi.org/10.1038/ srep08584

Zhang M, Zhang F, Fang Y, Chen X, Chen Y, Zhang W, Dai H-E, Lin R, Liu L (2015b) The non-canonical tetratricopeptide repeat (TPR) domain of fluorescent (FLU) mediates complex formation with glutamyl-tRNA reductase. J Biol Chem 290(28):1755917565. https://doi.org/10.1074/jbc.M115.662981

Zhang Z-P, Miao M-M, Wang C-L (2015c) Effects of ALA on photosynthesis, antioxidant enzyme activity, and gene expression, and regulation of proline accumulation in tomato seedlings under $\mathrm{NaCl}$ stress. J Plant Growth Regul 34(3):637-650. https://doi. org/10.1007/s00344-015-9499-4

Zhao A, Fang Y, Chen X, Zhao S, Dong W, Lin Y, Gong W, Liu L (2014) Crystal structure of Arabidopsis glutamyl-tRNA reductase in complex with its stimulator protein. Proc Natl Acad Sci USA 111(18):6630-6635. https://doi.org/10.1073/pnas.14001 66111

Zhen A, Bie Z, Huang Y, Liu Z, Fan M (2012) Effects of 5-aminolevulinic acid on the $\mathrm{H}_{2} \mathrm{O}_{2}$-content and antioxidative enzyme gene expression in NaCl-treated cucumber seedlings. Biol Plant 56(3):566-570. https://doi.org/10.1007/s10535-012-0118-y

Zhu J-K (2001) Plant salt tolerance. Trends Plant Sci 6(2):66-71. https ://doi.org/10.1016/S1360-1385(00)01838-0 